\title{
Why Democracies Cooperate More: Electoral Control and International Trade Agreements
}

\author{
Edward D. Mansfield, Helen V. Milner, \\ and B. Peter Rosendorff
}

Over the past fifty years, barriers to international trade have decreased substantially. While the decline in protectionism since World War II has stemmed partly from unilateral changes in trade policy by countries, it has also been a result of agreements among countries to liberalize commerce. In this article, we analyze the conditions under which states have concluded such agreements and, more generally, explore the domestic factors affecting interstate economic cooperation. We argue that the likelihood of states cooperating on trade policy depends crucially on their regime type: as states become more democratic, they are increasingly likely to conclude trade agreements.

Our analysis has implications for two broad areas in the field of international relations. First, a large and influential body of research has emerged on the effects of regime type on the outbreak and resolution of interstate conflict, the durability of political-military alliances, the propensity of states to join intergovernmental organizations (IGOs), and various other aspects of foreign policy. ' Very little of this literature, however, focuses directly on the links between regime type and foreign economic policy. We conduct one of the initial analyses bearing on this important topic.

Earlier versions of this paper were presented at the 1998 Annual Meeting of the American Political Science Association, Boston; the 1999 International Economics Association World Congress, Buenos Aires; the 1999 Latin American Meetings of the Econometric Society, Cancun; the 2000 Southeastern Theory and International Economics Meeting, Houston; the 2000 Latin American and Caribbean Economic Association Annual Meetings, Rio de Janeiro; the 2000 Public Choice Society Annual Meetings, Charleston; and seminars at Brown University, the University of California, Riverside, the University of Michigan, the University of Rochester, the University of Southern California, UCLA, and Yale University. We are grateful to participants in these seminars and David Baldwin, Marc Busch, Peter Gourevitch, Joanne Gowa, David Lake, Lisa Martin, James Morrow, Jon Pevehouse, and Alastair Smith for helpful comments.

1. See, for example, Bueno de Mesquita and Lalman 1992; Bueno de Mesquita et al. 1999; Gaubatz 1996; Mansfield and Snyder 1995; Russett and Oneal 2001; and Russett, Oneal, and Davis 1998.

International Organization 56, 3, Summer 2002, pp. 477-513

(C) 2002 by The IO Foundation and the Massachusetts Institute of Technology 
Second, this article joins the debate over the causes of international economic cooperation. Many studies attribute variations in cooperation to features of the global system, especially the distribution of capabilities and international institutions. ${ }^{2}$ In contrast, much less research addresses the domestic sources of economic cooperation, and virtually none considers the influence of regime type. ${ }^{3}$ Furthermore, the few studies that have been conducted on this topic pertain only indirectly to international trade agreements. ${ }^{4} \mathrm{We}$ help fill this gap in the literature by conducting one of the first direct examinations of the effects of regime type on the establishment of trade agreements. Such agreements embody cooperation among their members because they involve mutual policy adjustments, entailing the reciprocal lowering of trade barriers.

Our analysis shows how international cooperation in trade can be influenced by the control that voters exert over political leaders-a factor that varies starkly between democracies and autocracies. The regular occurrence of fair and competitive elections is fundamental to all democracies. ${ }^{5}$ As G. Bingham Powell observes, "There is a widespread consensus that the presence of competitive elections, more than any other feature, identifies a contemporary nation-state as a democratic political system." Such elections vest the public with control over government leaders that is absent in nondemocratic polities. ${ }^{7}$ In democracies, political leaders must succeed at the polls to maintain office. To this end, they must gain the support of voters, whose attitudes toward the incumbent tend to depend heavily on their perceptions of recent economic performance. ${ }^{8}$ In contrast, elections held in autocracies are much less free and fair; they vest the populace with much less control over public officials and place few (if any) constraints on the autocrat's policy choices. In our analysis, the superior ability of elections in democracies to constrain leaders prompts democratic rulers to be more cooperative internationally than their nondemocratic counterparts.

Elections, however, are not the only domestic constraints leaders face. In any political regime, leaders must balance the policies that enhance their electoral prospects with those that meet the demands of special interest groups. ${ }^{9}$ In what follows, we model how this trade-off affects the optimal foreign economic strategy of political leaders operating in different regime types.

It is clear that international trade agreements may stem in part from the associated economic gains that leaders expect to derive. We do not explicitly model these gains

2. See, for example, Keohane 1984; Krasner 1976; and Milner 1992.

3. See, for example, Milner 1997; and Reinhardt 1996. For an exception, see Leeds 1999.

4. See Mansfield, Milner, and Rosendorff 2000; McGillivray and Smith 2000; Remmer 1998; and Verdier 1998.

5. See Dahl 1971, 1-5; and Schumpeter [1942] 1976, 269.

6. Powell 2000, 4.

7. Schumpeter [1942] 1976.

8. See, for example, Fiorina 1981; Kiewiet 1983; and Lewis-Beck 1988.

9. Grossman and Helpman 1994. 
here since others have done so. ${ }^{10}$ Equally important, but far more poorly understood, however, are the political gains that also motivate state leaders to cooperate in trade. The model we develop focuses on these domestic political incentives. It demonstrates that, as the fate of a government becomes more dependent on free and fair elections, its leaders derive increasing gains from trade agreements, prompting them to engage in greater cooperation with other countries on commercial issues. Hence, the probability of a country concluding an international trade agreement increases as its domestic institutions become more democratic.

This outcome occurs because trade agreements can enhance the utility of both heads of state and voters. Trade agreements convey information to voters about the activities of leaders; in turn, such information helps leaders retain office. This informational role is an important aspect of cooperative agreements, and-although more domestically-oriented - it supports the claims of Robert O. Keohane about the value of information provision in fostering international cooperation. ${ }^{11}$

Voters have heterogeneous preferences about trade policy. Depending on their factor endowments, some prefer higher levels of protection and others prefer freer trade. A purely vote-maximizing representative would therefore choose a tariff level that maximizes the utility of the median voter. However, trade barriers create rents for interest groups whose support policymakers may desire to win. Hence political leaders may seek to raise barriers beyond the level preferred by the median voter to create these rents. Constituents harmed by government rent seeking can threaten to remove the incumbent; politicians trade off increased rents with a decreased vote share at the next election.

Voters, however, face an informational problem in their attempt to monitor politicians; namely, they cannot distinguish perfectly between adverse economic shocks over which leaders have little control and economic adversity stemming from the extractive policies of leaders. Consequently, voters in a democracy may remove a leader from office during economic downturns, even if that individual has not engaged in rent seeking. Leaders in such situations would like to find a way to demonstrate that poor economic performance is not the result of their extractive policies.

Entering into a trade agreement with another country is one way to do so. We argue that such agreements offer a more credible means for leaders to signal voters about their policy choices than do unilateral policy declarations, which leaders may be able to quietly reverse at any time. A trade agreement is defined here as (1) a public commitment by leaders to a less protectionist policy than otherwise would be implemented, and (2) an institutional device that credibly conveys that a state's obligations have been violated in the event of unilateral abrogation. A trade agreement, then, is both a promise and an alarm. It commits each participating

10. See, for example, Bagwell and Staiger 1999.

11. Keohane 1984. 
country to lower at least some trade barriers, and countries that violate their international commitments trip an alarm sounded by other participants or the organization monitoring the agreement.

Our model thus emphasizes the signaling function of international agreements. Reporting on the behavior of signatories is a key, although frequently overlooked, function of many commercial agreements. The World Trade Organization (WTO), for example, regularly issues public reports on all of its members' trade policies. These trade policy reviews are an important means by which countries' behavior can be monitored. In addition, its dispute settlement mechanism publicizes suspected violations of the agreement. The European Union (EU) also issues public summaries of the extent to which countries are adopting and implementing its directives. ${ }^{12}$ The North American Free Trade Agreement (NAFTA)'s dispute settlement mechanism serves a similar purpose-countries can be publicly accused of violating their international commitments and forced to undergo a long, open process of defending their behavior. We do not claim that voters actually read these documents, but rather that they are more likely to hear about a foreign government's or international organization's complaints regarding their government's violations of a trade agreement than they are to learn about changes in domestic trade policy. Such international accusations of bad behavior are more newsworthy than are unilateral changes in trade policy, as many countries (such as Mexico and Canada during the negotiations over NAFTA) have realized.

Furthermore, publicly exposed cheating on trade agreements can generate domestic "audience costs" for political leaders. ${ }^{13}$ Voters become aware that economic downturns may be attributable to leaders' overly protectionist policies and so become more likely to remove them from office. Recent public opinion research, for example, suggests that voters value commercial institutions-like the WTO-and believe they are needed to support an open trading system, implying that leaders may pay a political price for violating the rules of such institutions. ${ }^{14}$ These audience costs tend to be higher in democracies than in other regimes because the political survival of democratic leaders hinges more on election outcomes. International economic cooperation can thus help democratic governments boost their chances of re-election, thereby providing a strong inducement for them to pursue such agreements. Autocratic leaders, however, have less reason to worry about voters and consequently face less pressure to solve the informational problems addressed in this article by concluding commercial agreements.

The model we develop demonstrates that leaders have greater political incentives to conclude trade agreements as elections grow in importance. We expect, therefore, the probability of signing an agreement to increase as a country becomes more democratic. To test this hypothesis, we examine whether the regime types of states

12. Martin 2000 , chap. 7

13. Fearon 1994.

14. Herrmann, Tetlock, and Diascro 2001. 
have influenced their propensity to form and expand preferential trading arrangements (PTAs) during the period since World War II. Consistent with our model, we find that democratic countries are about twice as likely to form a PTA as autocratic countries, and that pairs of democracies are roughly four times as likely to do so as autocratic pairs. These results provide strong evidence that democracies are more commercially cooperative than other countries.

\section{The Model}

We begin by specifying the nature of the underlying economy, which allows us to derive the trade policy preferences of voters. Then we model the structure of the polity, deriving the government's preferences over trade policy. We use an imperfect information model where there is uncertainty about the state of the world. Consequently, voters do not know exactly what policy leaders choose. The extent to which a state is democratic influences how much impact elections have on the probability that a leader retains office, given the voters' choices and the policies adopted. We first derive a Nash equilibrium for the purely domestic game between voters and the government in setting the level of trade barriers. Then we derive the Nash equilibrium for the same game, except that we allow governments to sign trade agreements with other countries. We show that allowing them to make agreements can generate gains for both governments and voters compared to the no-agreement case, and that the gains accruing to governments are directly related to the extent of democracy. Finally, we show that the model indicates that the probability of a trade agreement being signed by two countries increases as either country becomes more democratic. The appendix contains the complete formal derivation of our results.

\section{The Economy}

We analyze a small, open Heckscher-Ohlin economy producing two goods with two factors of production, as the appendix further specifies. The domestic price of the imported good (in terms of the export good) in period $\tau$ is $p_{\tau}$, and $p_{\tau}=\pi_{\tau}\left(1+t_{\tau}\right)$ where $\pi_{\tau}$ is the world price (in period $\tau$ ) and $t_{\tau}$ is the current period level of trade barriers, modeled here as an ad valorem tariff. Because the economy is small, the world price $\left(\boldsymbol{\pi}_{\tau}\right)$ is given and cannot be affected by states' actions. Without any loss of generality, we normalize the price such that trade ceases at $t_{\tau}=1$ (that is, the tariff is prohibitive at 100 percent).

Individuals in the economy maximize the discounted sum of their one-period utilities, which depend on domestic prices and the tariff in two ways. A higher domestic price of the imported good (perhaps due to tariffs) lowers consumption of that good, but if the individual's income rises with protection, consumption (and hence utility) may rise. We can write any individual $l$ 's utility as a function solely of domestic prices (which in turn depend on the tariff) as 


$$
U^{l}=\sum_{\tau=0}^{\infty} \delta^{\tau} U^{\prime}\left(p_{\tau}\right)
$$

Voters differ in their ownership of capital; as such, they differ in the level of protection that each desires most. Since we assume that the imported good is labor-intensive, those individuals who own much capital prefer low or even negative tariffs, whereas those who own little but their labor prefer higher tariffs. We assume that the median voter, indexed by $m$, owns relatively little capital, and therefore prefers a positive, but moderate, level of trade barriers, denoted $t^{m}$.

This assumption about voters' trade preferences is entirely appropriate. In the United States, which is among the least trade-dependent countries, public opinion data show that a vast majority of elites and a majority of the mass public support relatively free trade. ${ }^{15}$ In more trade-dependent countries, such sentiment is likely to be even stronger.

\section{The Polity}

The executive (also called the incumbent or the government)-whether a democratic or autocratic leader-is a pure rent seeker unconcerned about social welfare. ${ }^{16}$ The executive may extract rents either directly via trade tax revenues or indirectly from interest groups in exchange for trade barriers that shield these groups from foreign competition. We adopt a very general objective function for government rents, $G(t)$. It is assumed to be an increasing function of home trade barriers, $G^{\prime}(t)>0$. The executive wishes to maximize the sum of the discounted ${ }^{17}$ rents collected by the government,

$$
G=\sum_{\tau=0}^{\infty} \delta^{\tau} G\left(t_{\tau}\right) .
$$

The government is a pure rent seeker, and these rents rise monotonically with the level of protection. This purely venal behavior implies that any predictions we make about the limits on the extractive behavior of leaders stem from the institutional structures within which policies are chosen, rather than from the players' preferences. Furthermore, any variations in policy choice across regimes will be a consequence of institutional variation, not of variations in preferences.

15. See Chittick and Billingsley 1989; and Herrmann, Tetlock, and Diascro 2001.

16. Social or consumer welfare does not enter the government's objective function, making our claims harder to establish.

17. We assume that the discount rates of voters and the government are the same, but that their utility functions are different. 
This assumption also ensures that the government will, ceteris paribus, always desire a level of tariffs higher than voters prefer. This tension between voters and leaders-with voters attempting to restrain an extractive leader-is central. Alternatively, we could specify the government's preferences as single-peaked in the tariff. For example, the government may receive a share of the tariff revenues, so that the point at which these are maximized is the preferred level of tariffs of the government. All the same results follow as long as we maintain the assumption that the government's unconstrained, ideal tariff is higher than that of the median voter.

If the government's ideal tariff were to lie below that of the median voter, the political problem facing the voters would be different. No longer would they have to restrain the rent-seeking impulses of their leaders; instead they would encourage leaders to choose higher tariffs. If voters are highly protectionist, and even more so than leaders, the decision to establish trade agreements is itself puzzling. One then has to explain why leaders would negotiate public agreements to adopt policies that are opposed not only by many special interest groups (for example, importcompeting groups), but also by a majority of the populace. Our model does not deal with this ordering of preferences.

The voters' problem is informational. Voters are incompletely informed about the exact level of trade barriers, but they do know the domestic price of the goods they produce and consume. ${ }^{18} \mathrm{We}$ assume that the world price, $\pi_{\tau}$, is subject to exogenous shocks in each period. The distribution of these shocks is given and known to all. ${ }^{19}$ Voters, however, cannot determine exactly how the shocks and government policy combine to affect domestic goods prices.

The sequence of events in each period of our model is as follows: the executive decides on the government's trade policy, $t_{\tau}$, and then the world economy experiences a shock to world prices, $\pi_{\tau}$. These two events together determine domestic prices, $p_{\tau}$, which are what voters observe. Prices and incomes are then established, and consumption occurs, all of which determine the voters' welfare. At the end of each period, the median voter examines its welfare, $U^{m}$, which determines its support for or opposition to the incumbent in the election. If the voter's welfare is above some threshold level, which is determined endogenously, then it votes to re-elect. This one-shot game is repeated ad infinitum.

The executive must commit to a trade policy before the shock has materialized. That is, the government must choose policy in the face of uncertainty about the world price that will be obtained. Once the shock materializes, its magnitude is still unknown to the voters, as is the tariff chosen. In the case of an adverse shock, voters cannot tell if the low utility they experience was caused by an exogenous shock to

18. It is not obvious that voters know the exact policy choices of their representatives. For example, United States voters are much more likely to know the domestic price of sugar than the level of the quota imposed on imported sugar by the government.

19. These shocks to the exogenous world price are identically and independently distributed (i.i.d.) in each period over a finite support. 
the economy or by excessive protectionism on the part of the executive. Voters base their electoral decision only on the information available to them, implying that they may reject executives for events that are beyond the executives' control. The executive thus faces the prospect of being ousted from office in every electoral period.

The voters will choose a voting rule conditional on the observed domestic price and hence their current period utility. This simple retrospective voting rule is one in which the voters optimally choose a threshold level of utility, $\underline{U}^{l}$, such that voter $l$ will choose to reappoint the executive in period $\tau$ if $l$ 's utility is at least as good as its threshold value, that is, if $U^{l}\left(p_{\tau}\right) \geq \underline{U}^{l}$.

We define the (ex ante) probability of the median voter recommending reappointment as the probability that actual utility (as a consequence of the policy $t_{\tau}$ and the shock $\left.\pi_{\tau}\right)$ is larger than the specified threshold $\underline{U}^{m}$. That is $\phi\left(t_{\tau}, \underline{U}^{m}\right)=$ $\operatorname{Pr}\left[U^{m}\left(p_{\tau}\right)>U^{m}\right]$. We assume that $\phi(1, U)=0$ for all $U$. That is, when trade barriers are set so high that imports are prohibited, the electorate fails to vote for re-election with certainty. ${ }^{20}$

\section{Political Regime Type}

An election is a determination by voters about whether the executive should remain in office. Both democracies and autocracies hold elections. What differs across regimes is the degree to which these contests affect the executive's fate. The more democratic a country, the more important are elections in determining whether the incumbent retains office. If the election's outcome is binding, the regime is a "pure democracy." If, on the other hand, the executive retains office irrespective of the voters' decision, the regime is a "pure autocracy."

We allow a continuum of possibilities for the role of elections and hence for the type of regime: the degree to which the election binds the executive ranges from low to high. That is, the actual probability that the executive keeps office is a weighted average of the probability in a pure democracy and the certainty of keeping office in a pure autocracy. The actual probability of keeping office in any period, $\tau$, is:

$$
\rho\left(t_{\tau}, \underline{U}^{m}, \sigma\right)=\sigma \phi\left(t_{\tau}, \underline{U}^{m}\right)+(1-\sigma) \text { where } \sigma \in[0,1] \text {. }
$$

The variable, $\sigma$, indicates a country's regime type and takes on higher values in more democratic polities. In a pure democracy, $\sigma=1$. Only the support of the voting public determines whether a leader retains office. In a pure autocracy, by

20. Equivalently, $U^{l}\left[\pi^{\text {min }}(1+1)\right]<U$ for all $U>0$ and for all individuals, $l$, where $\pi^{\text {min }}$ is the minimum value in the support of $\pi$. That $\phi(1, U)=0$ for all $U$ is a feature of the political system, not of the preferences of the government. That is, in all systems, complete rent extraction leads the electorate to recommend eviction from office. 
contrast, $\sigma=0$. The incumbent executive keeps office irrespective of the electorate's sentiments. ${ }^{21}$

\section{The Executive's Optimal Level of Trade Barriers}

Given that the economy is small, the executive can choose trade barriers without being able to affect world prices and hence other countries' policy decisions, and vice versa. Each executive will choose a level of trade barriers that balances the threat of rejection at the polls with the gains from rent seeking, independent of the foreign country's behavior. Because we are examining the behavior of all countries in the world, it is appropriate to assume that the average country lacks global market power. Very few countries ever have enough market power to affect world prices for any good, let alone for all goods in the economy.

In any period, $\tau$, after choosing domestic trade policy $t_{\tau}$, the executive gains $G\left(t_{\tau}\right)$. The value of choosing $t_{\tau}<1$ at the start of any period, $\tau$, can be written (recursively) as

$$
\Gamma_{\tau}\left(t_{\tau}\right)=G\left(t_{\tau}\right)+\delta \rho\left(t_{\tau}, \underline{U}^{m}, \sigma\right) \Gamma_{\tau+1} .
$$

The executive chooses the current period's trade policy, taking the future play of the game as given $\left(\Gamma_{\tau+1}\right.$ is the continuation value of the game). The decision reached today affects today's rents and the probability of re-election, but does not affect the level of extraction undertaken tomorrow (because the shocks are i.i.d.). Maximization of equation (2) determines the government's optimal choice of trade policy, which we label $t$. The optimal choice of trade barriers exactly balances the gains in rents from higher barriers with the reduced likelihood of re-election. We show in Lemma A.1 (in the appendix) that, as the voter's choice of the threshold level of welfare rises, the optimal tariff rate chosen by the incumbent $\left(t^{\circ}\right)$ must decline. Voters can thus exercise control over their government.

The executive can adopt an alternative strategy, however, which we label the Leviathan strategy. In this course of action, the government maximizes its economic extraction by setting tariffs at their highest level, $t=1$, and consequently reducing its prospects of re-election. There is still some chance that a maximally extractive government will remain in office in the next period despite the will of the voters

21. It has been suggested that a key distinction between democracies and autocracies is that democratic leaders are less patient (that is, have lower discount factors) and are only concerned about the next election, whereas autocratic leaders have a longer time horizon. See, for example, Haggard and Kaufman 1995, 152. Our model formalizes this intuition by incorporating the role of elections into leaders" decision making. If the election is substantively important, the effect of the election is, in equilibrium, to lower the implied discount factor that leaders use to calculate their future (expected) stream of rents. The leader's effective discount rate is shown endogenously to be lower the more democratic the state. 


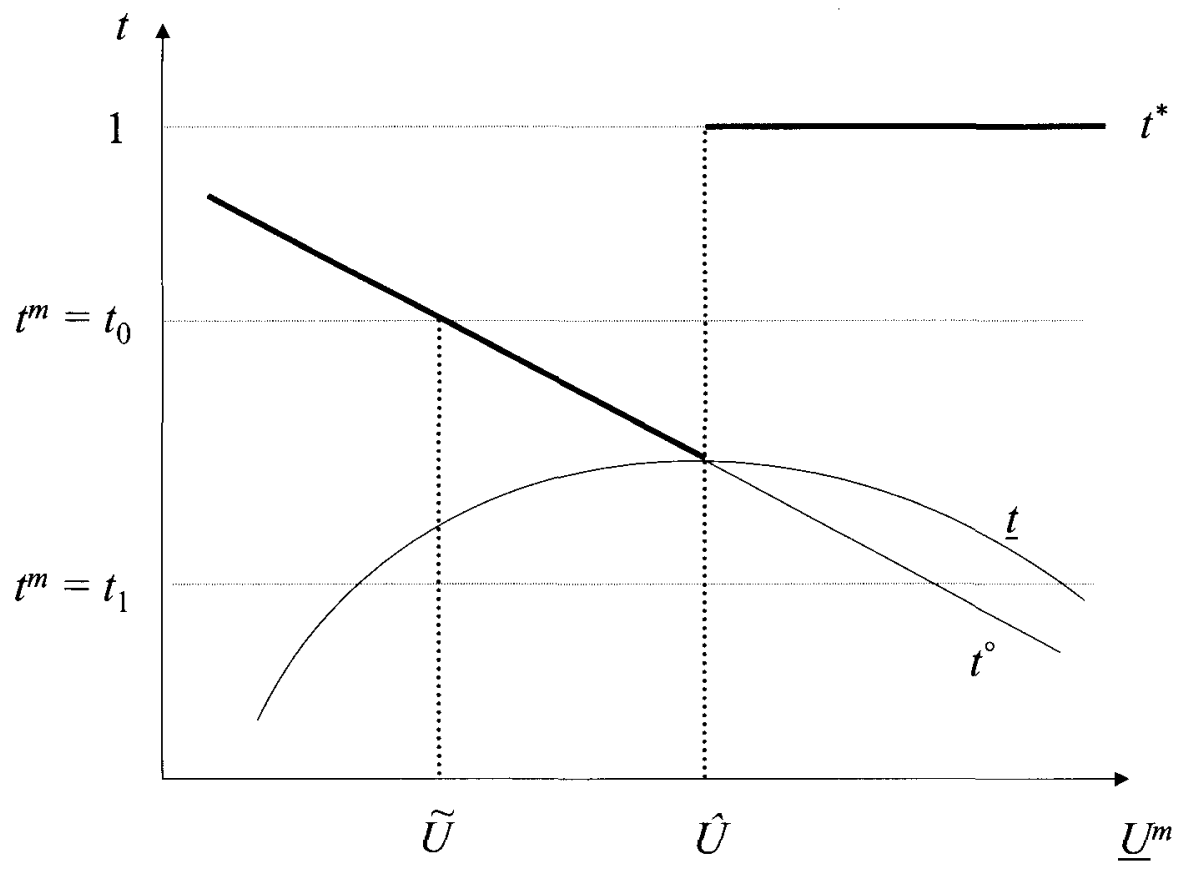

FIGURE 1. The best response functions

because the country is not a perfect democracy. This happens with probability 1 $\sigma$. A lower tariff, $t$-one that balances the rent extraction motive with re-election concerns as in $t^{\circ}$ above - is preferred by the incumbent over the Leviathan tariff, $t=$ 1 , when the executive gains more from the lower tariff than from the Leviathan policy. The incumbent's optimal choice between the maximal Leviathan tariff and the moderate tariff then depends on the voters' selection of their welfare threshold, $\underline{U}$. Setting the threshold too high requires the government to choose a very low tariff; in response, the incumbent may choose the Leviathan action, extracting the maximal amount of rents now and risking rejection in the future election. If the threshold is set too low, the government extracts as much as possible, ensuring that the low utility threshold of the voters is still satisfied. Hence the choice of tariff depends crucially on the threshold chosen by the voters. Figure 1 illustrates the government's best response function, indicated in bold.

There is some threshold $(\hat{U})$ that is the highest the incumbent will accept before resorting to the Leviathan action. And since the optimal tariff, $t^{\circ}$, falls with the threshold (see Lemma A.1 in the appendix), there is some minimum tariff level, $\underline{t}$, which the incumbent will accept. This tariff, $t$, is calculated to be the lowest that the executive will accept instead of adopting the maximally extractive, Leviathan tariff; 
the executive is indifferent between the Leviathan and this moderate tariff. Any attempt by the voters to restrict the tariff below this level by raising their welfare threshold induces the government to choose the Leviathan strategy. Any tariff above this minimum level is preferred to the Leviathan tariff by the government. Thus voters have some, but not complete, control over the government through the threat of elections.

\section{Optimizing Voter Behavior}

If the government adopts the Leviathan strategy of maximal tariffs, then there is no role for the voters regardless of their welfare threshold. If, instead, the government adopts a more moderate strategy, then the voters (who select their thresholds before the government implements its tariff policy) choose a threshold to maximize their expected utility:

$$
E U(p)=E U\left\{\pi\left[1+t^{\circ}\left(\underline{U}^{m}, \sigma\right)\right]\right\}
$$

\section{The Nash Equilibrium}

Consider again Figure 1. In the region where $t^{\circ}$ lies above $t$-that is, where $U<$ $\hat{U}$ - the optimal response by the government to any $U$ is $t$. When $U$ gets too large, the government switches to the Leviathan strategy and adopts the maximal tariff of 1 .

The median voter wants a tariff that lies as close as possible to her (ex ante) ideal, $t^{m}$. If $t^{m}$ lies everywhere above $\underline{t}$ (as in the case where $t^{m}=t_{0}$ in Figure 1 ), then the voter sets the threshold at $\tilde{U}$ and the government responds with $t^{\circ}=t^{m}$. Alternatively, when $t^{m}$ crosses $\underline{t}$, the voter's ideal tariff lies below that which the government can be constrained to provide. Hence, the voters restrict the government to the lowest tariff possible by choosing a threshold at $\hat{U}$. We prove that this pair of strategies is a Nash equilibrium in Lemma A.3 in the appendix.

If the government is perfectly constrained by voters, then $t^{m}$ is the tariff imposed in response to the threshold of $\tilde{U}$. If, however, the government is imperfectly controlled by the voters, then the government implements a tariff of $\underline{t}(\hat{U})$ in response to $\hat{U}$. The degree of control that the voters exercise depends crucially on whether $t^{m}$ is larger or smaller than $t(\hat{U})$. Now $t^{m}$ is exogenous; $t(\hat{U})$, on the other hand, is the lowest tariff the executive is prepared to accept before switching to the maximally extractive, Leviathan tariff.

The value of the equilibrium tariff, $\underline{t}$, that leaves the executive indifferent between playing it or the Leviathan strategy, depends on the degree of control the voters exercise over the executive, that is, on $\sigma$, the level of democracy (see Lemma A.4 in the appendix). However, more democratic polities will not necessarily adopt lower tariffs in the equilibrium to this tariff-setting game. As the polity becomes more democratic, the benefits of the Leviathan tariff fall because the executive 
becomes more likely to be replaced when selecting this strategy. To maintain the indifference condition between (the payoffs from) $t$ and the Leviathan strategy, the benefits generated by a more moderate tariff must fall as well; thus $t$ should fall. But a lower $\underline{t}$ also increases the likelihood of re-election in the next period and hence keeps the government in office longer in expectation. This latter effect raises the long-run returns to the government, causing the indifference condition between $\underline{t}$ and the Leviathan tariff to be violated once again. The relative size of these two effects is indeterminate at our level of generality. Hence, it is not necessarily true that more democracy leads to lower unilateral tariffs.

Although the equilibrium tariff, $t$, is determined by both the preferences of the players and the domestic institutions that govern the voters' control of the executive, it is not necessarily the case that, as domestic institutions become more democratic, the equilibrium tariff, $t$, in this game falls. Democracies, in our model, are not unilaterally freer traders than other regime types. ${ }^{22}$

In what follows, however, we show that democracies are more likely to join PTAs than other countries. Moreover, we establish that democracies do not join PTAs solely to lower trade barriers. A more interesting and deeper result related to PTA formation grows out of the model: such arrangements can solve an informational problem that limits the head of state's credibility. In the eyes of the voters, participating in a PTA bolsters the credibility of offers made by the executive to reduce trade barriers, and enhances the leader's prospects of re-election.

In the next section we compare the gains for the executive from the unilateral policy choice described above to those reaped from signing an international trade agreement. We show that both voters and executives can be made better off with an agreement, and that this is increasingly true as a country becomes more democratic.

\section{International Cooperation and Trade Agreements}

In addition to setting their own unilateral policies, executives have the capability to negotiate trade agreements with other countries. But an executive will only do so if the gains from an agreement are at least as great as those from setting policy

22. The unilateral, equilibrium tariff (under imperfect control) is the lowest tariff the executive will accept rather than adopt the maximally extractive, Leviathan action; That is, in equilibrium, the executive plays $\underline{t}$ and earns a return identical to the Leviathan payoff, $G(t) /\{1-\delta[\sigma \phi(\underline{t}, U)+(1-\sigma)]\}=$ $G(1) /[1-\delta(1-\sigma)]$. As the polity becomes more democratic (as $\sigma$ rises), the benefits of the Leviathan action fall; that is, the right-hand side falls. As the right-hand side falls, so does the left-hand side, but the left falls by less. To maintain the indifference condition, the benefits of a moderate action (the left hand side) must fall even more. A fall in the moderate tariff, $\underline{t}$, reduces the benefits to the government in any period $(G(t)$ falls). But it also increases the likelihood of re-election $(\phi(\underline{t}, U)$ rises) and hence keeps the government in office longer in expectation. This might raise the discounted returns to government, violating the indifference condition. Hence it is not necessarily true that more democracy leads to lower unilateral tariffs. It depends on the particular functional form of the distribution function $\phi(t, U)$ that captures the uncertainty relative to the shape of government's objective function $G(t)$. See Lemma A.4 for the implicit differentiation of the equality above. 
unilaterally. When can an executive gain from a trade agreement? An agreement is a pair of trade policies and a signaling institution. The signal may be a complaint filed by another country that is party to the agreement or a determination of non-compliance by the international institution monitoring the agreement. That is, an agreement by definition comprises a level of trade barriers lower than the executive's optimal unilateral policy, $t^{C}<t^{*}$. It also includes a mechanism for the institution or a foreign country to signal others that the home executive has cheated and raised trade barriers above the agreement level. Consequently, the agreement trips an alarm if $t>t^{C}$; otherwise, no signal is sent.

The agreement, then, is a level of trade barriers below the government's ideal unilateral level and an alarm mechanism that other governments or a trade institution-such as the General Agreement on Tariffs and Trade (GATT) or the WTOcan use whenever the actual trade policy of a party to the agreement deviates from the one agreed upon. A commercial agreement is public and therefore provides information that voters can use to more closely monitor the executive. In particular, monitors of the trade agreement (such as an independent agency like the WTO or even the participating governments themselves) can announce, just before each election, whether the executive in each country is in compliance with the agreement. $^{23}$

We assume that voters can observe this signal. Moreover, voters have an incentive to pay close attention to it, since the signal improves their welfare. Equally, the trade institution and its members have an incentive to divulge this information and make sure that voters pay attention to it, since this disciplines the government. Our assertion is that voters are more likely to hear about a foreign country's or an international organization's accusations that their government violated a trade agreement than they are to know about a unilateral change in domestic trade policy. We expect that international accusations of violations will be much more newsworthy than marginal, unilateral changes in the tariff code. An international trade agreement, then, both sets policy and provides information.

Under an international trade agreement, the executive will abide by the terms of the agreement whenever the long-term gains from doing so exceed the gains from the Leviathan strategy. The voters reward a compliant executive by setting a zero threshold; that is, they always vote to re-elect the government. If the agreement is violated, the voters set an unreachable threshold and vote to reject the incumbent with certainty. Lemma A.5 establishes that this is equilibrium behavior for both the executive and the voters.

23. As noted earlier, the WTO does indeed issue such reports on all member countries periodically. Its trade policy reviews of member countries are an important aspect of monitoring, as is its dispute settlement system. 


\section{Comparing the Regimes: Imperfect Control and Gains for the Executive}

When the voters can only imperfectly control the executive, can the executive still gain from the agreement relative to the no-agreement situation? The agreement decreases the tariff below what was the lowest acceptable tariff in the absence of the agreement, that is, $t^{C} \in\left[t^{m}, t\right]$. Since the voters prefer a tariff lower than $\underline{t}$, they obviously gain (or at least no worse off). Does the government gain?

We assume that the voting rule for individuals casting ballots adjusts to the new information the agreement provides. The probability of re-election still depends on their overall utility, but voters also make use of the information embedded in the alarm. If no alarm sounds, it is optimal for the median voter to cast a ballot for the incumbent. After all, the agreed-upon tariff is, by definition, preferred to the tariff absent the agreement. On the other hand, if the alarm sounds, the median voter rejects the incumbent, although there is still the $(1-\sigma)$ chance that the offending government manages to hold onto office.

The value of international cooperation over noncooperation for the executive is the difference between the executive's gains from cooperation and the gains from unilateral policymaking:

$$
\Delta\left(t^{C} ; \sigma\right)=\frac{G\left(t^{C}\right)}{1-\delta}-\frac{G(1)}{1-\delta(1-\sigma)} .
$$

PROPOSITION 1: Under imperfect voter control, for any $t^{C} \in\left[t^{m}, t\right]$,

a) the agreement is preferred by governments that are sufficiently democratic and patient, that is, $\Delta\left(t^{C}, \sigma\right)>0 \forall \sigma>\bar{\sigma}(\delta)$;

b) the more democratic the polity, the greater the gains from cooperation, that is, $d \Delta / d \sigma>0$.

In Proposition 1, we show that the more democratic the country, the more its government prefers the international agreement. Proposition 1 also shows that the gain to the executive from cooperating increases as the state becomes more democratic. As the level of democracy, $\sigma$, rises, the probability of being removed from office grows even when the executive is not overly extractive, ceteris paribus. Hence, relative to an autocrat, a democratic executive (whose re-election is more dependent on the wishes of voters) has more to gain from making an agreement and thus lowering the chance of eviction from office without a legitimate cause. The executive trades off a greater degree of certainty about re-election when he cooperates in exchange for a lower level of rents because he chooses a lower level of trade barriers.

Notice that any trade agreement, $t^{C} \in\left[t^{m}, t\right]$, yields a gain for the executive. The best possible agreement (for the executive) may be to agree to a tariff as close to $t$ 
as possible. Little would be relinquished in the trade negotiations, but much would be gained in terms of the domestic polity. Recall, of course, that we have abstracted from other motivating factors that induce states to form PTAs, such as the welfare gains from trade creation and the political gains from trade diversion or from deep integration, all of which might induce an executive to lower tariffs even further. But our primary concern here has been to establish the role that an agreement can play in solving the domestic monitoring problem.

\section{Comparing the Regimes: Perfect Control and Gains for the Executive}

In the case where the median voter exercises perfect control over the government (that is, $t^{*}=t^{m}$ ), it is also the case that the government will gain from the agreement. The extra information provided by the agreement reduces the chance that the government is unfairly evicted. Consider the case where the agreement sets tariffs equal to those favored by the median voter; that is, $t^{C}=t^{m}$. This agreement then merely formalizes pre-existing behavior. Then the gains for the executive from international cooperation relative to noncooperation now are

$$
\Delta\left(t^{m} ; \sigma\right)=\frac{G\left(t^{m}\right)}{1-\delta}-\frac{G\left(t^{m}\right)}{1-\delta\left[\sigma \phi\left(t^{m}, U\right)+(1-\sigma)\right]}
$$

In this case, as Proposition 2 demonstrates, the international agreement is preferred by executives in all regime types, yet it is democratic executives that have the most to gain from these agreements. The executive's gains from signing an agreement rise with the country's level of democracy.

PROPOSITION 2: Under perfect control, for any agreement $t^{C}=t^{m}$,

a) $\Delta\left(t^{C} ; \sigma\right)>0$ for all $\sigma$;

b) the more democratic the polity, the greater the gains from cooperation, that $i s, d \Delta / d \sigma>0$.

\section{The Voters' Gain from the Cooperative Agreement}

Even if the government gains, we need to show that the voters gain as well from an international agreement in all situations. In the case where the government is imperfectly constrained by voters in the absence of a trade agreement, it is balancing two pressures. The first induces the incumbent to extract as much rent as possible by applying a very high tariff, while the second pushes him to limit his extraction so he does not reduce his chances of re-election too much. The net effect is to choose a tariff that is higher than that preferred by the median voter; hence, $t^{*}>t^{m}$. Thus any international agreement that lowers the actual tariff below $t^{*}$ and closer to the 
median's ideal, $t^{m}$, will be preferred by the median voter. As such, the median voter prefers any international agreement $t^{C} \in\left[t^{m}, t^{*}\right)$ to the lack of an agreement.

If the government is perfectly constrained by the voters, no improvement with respect to the voters' utility is possible from an international agreement. The agreement at the pre-existing tariff level-the median voter's ideal level-is beneficial to the government but leaves the voters indifferent. (The government will not agree to an international agreement that lowers tariffs below both its and the median voter's ideal level since this will lower its utility and spur its removal from office.) Given these conditions, the median voter weakly prefers the international agreement to the lack of one, as Proposition 3 formally proves.

PROPOSITION 3: The median voter prefers the trade agreement regime to the no-agreement regime.

In a world where voters cannot perfectly distinguish between a reduction in utility stemming from an adverse economic shock, on the one hand, and from excessive government rent seeking, on the other, executives and voters will both gain from international trade agreements that provide information about the executive's behavior. Thus we have our central result: the incentives for a leader to sign a trade agreement increase as the country becomes increasingly democratic. As such, the more democratic the polity, the greater the likelihood that the country will sign a trade agreement.

\section{The International Game}

For any international trade agreement to be signed, at least two countries must agree. How do both (or all) countries' gains change when the home country becomes more democratic? In this model, because the countries are small, the behavior of each has no impact on the other. An increase in one country's level of democracy has no impact upon the other country's willingness to sign an agreement.

If the probability of signing a trade agreement increases in the gains from such an agreement, then the probability of an agreement depends independently on the level of democracy in each country. As one country becomes more democratic, the other countries' willingness to sign an agreement never falls. Therefore, the probability of an agreement between two or more countries always rises as the level of democracy in any one of them increases. Moreover, the model implies that, although their effects are independent, when each country is very democratic the probability of a trade agreement is highest. It is lowest when each country is very autocratic.

Let $F_{i}$ and $F_{j}$ be the probabilities that countries $i$ and $j$, respectively, sign a trade agreement. Since these probabilities are increasing in the gains from this agreement, we know from Propositions 1 and 2 that the gains from the agreement depend on the tariff levels chosen and the degree of democracy in each country. Thus we have $F_{i}=F\left[\Delta\left(t^{C} ; \sigma_{i}\right)\right]$ and $F_{j}=F\left[\Delta\left(t^{C} ; \sigma_{j}\right)\right]$, with $F$ being a continuous function that 
takes a value between 0 and 1 , and rises with $\Delta$. Then the probability that a PTA forms between $i$ and $j$ is simply the product of these two probabilities: $\operatorname{Pr}\left(P T A_{i j}\right)=F_{i} F_{j}=F\left[\Delta\left(t^{C} ; \sigma_{i}\right)\right] F\left[\Delta\left(t^{C} ; \sigma_{i}\right)\right]$. Since both of these depend on the level of democracy, we have the following proposition.

PROPOSITION 4: The probability that two countries form a PTA rises with the level of democracy in each country. That is,

$$
\frac{d \operatorname{Pr}\left(P T A_{i j}\right)}{d \sigma_{i}}>0 \text { and } \frac{d \operatorname{Pr}\left(P T A_{i j}\right)}{d \sigma_{j}}>0
$$

Democracies have a greater incentive to enter into cooperative trade agreements than other polities. There are, of course, other, more standard arguments for trade agreements, especially in the small, open-economy environment assumed here. The economic costs and benefits of joining such arrangements have been extensively studied and are clearly important. ${ }^{24} \mathrm{We}$, however, focus on another key determinant of the decision to form a commercial arrangement that has been the subject of remarkably little research to date, namely, the regime types of the member states.

\section{The Empirical Evidence}

The preceding analysis indicates that a country is increasingly likely to conclude a cooperative trade agreement as it becomes more democratic and that the probability of two or more countries signing such an agreement rises with the level of democracy in each country. In the remainder of this article, we conduct some preliminary statistical tests of these propositions.

We focus on explaining agreements that establish or expand PTAs - a group of institutions that includes customs unions, common markets, free trade areas, and other commercial agreements. Reductions in reciprocal trade barriers among participants are central to all such arrangements. In fact, Article XXIV of the GATT stipulates that any PTA notified to this body must largely abolish barriers to commerce within the preferential grouping. ${ }^{25}$ States making reciprocal trade barrier reductions are engaged in acts of economic cooperation, so it is appropriate to test our model of cooperative trade agreements by focusing on the formation and expansion of PTAs. ${ }^{26}$ It is clear that agreements to enter into a preferential trading

24. See Anderson and Blackhurst 1993; Bhagwati 1993; de Melo and Panagariya 1993; Fernández and Portes 1998; Krueger 1999; Pomfret 1988; Panagariya 2000; and Whalley 1998.

25. See Anderson and Blackhurst 1993; Bhagwati 1993, 27; and de Melo and Panagariya 1993.

26. It is important to note that whether such trade barrier reductions adversely affect third parties has no bearing on whether the reductions constitute acts of economic cooperation among the PTA members. As Lisa L. Martin points out, "While cooperation improves the expected welfare of the cooperating states relative to the status quo ex ante, it is not necessarily a Pareto-improving (mutually beneficial) move for 
arrangement do not constitute the entire universe of trade agreements to which this model could be applied. Nonetheless, PTAs comprise a substantial portion of the commercial agreements concluded since World War II, which is the period analyzed here. Furthermore, comprehensive data on other such agreements are not available for many countries included in our sample.

\section{A Statistical Model of PTAs}

Proposition 4 demonstrates that the probability of two countries signing a trade agreement is a positive function of the level of democracy in each country. To test this formal proposition, we estimate the following model of PTA formation:

$$
\begin{aligned}
P T A_{i j}= & \beta_{0}+\beta_{1} R E G_{i}+\beta_{2} R E G_{j}+\beta_{3} G D P_{i}+\beta_{4} G D P_{j}+\beta_{5} \Delta G D P_{i} \\
& +\beta_{6} \Delta G D P_{j}+\beta_{7} T R A D E_{i j}+\beta_{8} D I S P U T E_{i j}+\beta_{9} C O L_{i j} \\
& +\beta_{10} A L L Y_{i j}+\beta_{11} D I S T A N C E_{i j}+\beta_{12} G A T T_{i j} \\
& +\beta_{13} H E G E M O N Y+e_{i j}
\end{aligned}
$$

The dependent variable is the log of the odds that a pair of states, $i$ and $j$, enters a PTA in year $\tau+1$, where we observe 1 if this occurs and 0 otherwise. We code $i$ and $j$ as entering a PTA if they-either by themselves or in combination with other countries-form a new preferential arrangement, or if one of them joins a PTA in which the other is already a member. Hence, the observed value of $P T A_{i j}$ is 1 in the year $i$ and $j$ enter a preferential arrangement, but not in years when they belong to a pre-existing arrangement. In the following analysis, however, we also briefly consider whether the variables in equation (4) help to explain the existence of a preferential grouping between $i$ and $j$. Although the PTAs included in our analysis are drawn primarily from those notified to the GATT, they also include other arrangements since there is no reason to limit our model's application to commercial agreements concluded among parties to the GATT. ${ }^{27}$

the world as a whole." Martin 2000, 13; see also Keohane 1984. It is also important to note that, although a large and influential body of literature exists on the economic effects of PTAs, the nature and strength of these effects remain subjects of fierce debate and have little bearing on our analysis. See, for example, Bhagwati 1993; Frankel, Stein, and Wei 1998; Krueger 1999; Krugman 1993; Panagariya 2000; and Pomfret 1988.

27. For a list of PTAs notified to the GATT, see World Trade Organization 1995. In addition to these PTAs-which are limited to arrangements formed by GATT and WTO members-we include the PTAs listed in Hartland-Thunberg 1980. We also include the Council on Mutual Economic Assistance (CMEA), the Southern African Customs Union, the Economic Community of West African States (ECOWAS), the Southern African Development Coordination Conference, and the Eastern and Southern African Preferential Trade Area. On these PTAs, see de Melo and Panagariya 1993; Foroutan 1993, 246-51; Hanlon 1986; Kisanga 1991; Orimalade and Ubogu 1984; and Pomfret 1988.

Each PTA is coded as starting in the year it enters into force. (Note that we do not consider agreements strengthening or superceding an existing PTA to be new preferential arrangements.) The original 
To measure each state's regime type, identified as $\sigma$ in the formal model above, we rely on a widely used index constructed by Keith Jaggers and Ted Robert Gurr. ${ }^{28}$ This index combines data on five factors that help to capture the institutional differences between democracies and autocracies that we emphasized earlier: the competitiveness of the process for selecting a country's chief executive, the openness of this process, the extent to which institutional constraints limit a chief executive's decision-making authority, the competitiveness of political participation within a country, and the degree to which binding rules govern political participation within it. Following Jaggers and Gurr, these data are used to create an 11-point index of each state's democratic characteristics (DEMOC) and an 11-point index of its autocratic characteristics (AUTOC). The difference between these indices, $R E G=D E M O C-A U T O C$, yields a summary measure of regime type that takes on values ranging from -10 for a highly autocratic state to 10 for a highly democratic country.

There are three principal reasons we rely on this measure in the following analysis. First, our formal model treats regime type $(\sigma)$ as a continuous variable, with the competitiveness of elections ranging from perfectly competitive to completely uncompetitive. As noted above, the index developed by Jaggers and Gurr has a range of 21 points, unlike some other measures of regime type. ${ }^{29}$ Second, their index highlights a number of institutional dimensions of regime type that we stressed. The ability of voters to choose the chief executive, which is central to our model, is expected to rise as the process for selecting the executive becomes more competitive and more open, and political participation becomes increasingly competitive. Jaggers and Gurr's index captures each of these three institutional elements, whereas various alternative measures do not. ${ }^{30}$ Third, their index covers more countries during the period since World War II than any other measure of regime type with which we are familiar. ${ }^{31}$

In equation (4), $R E G_{i}$ is the value of Jaggers and Gurr's measure for state $i$ in year $\tau$ and $R E G_{j}$ is the value of this measure for state $j$ in $\tau$. Which state in each pair is

members of every PTA are coded as joining it in this year. A state that enters an existing PTA is coded as having formed a preferential arrangement with each member of the arrangement in the year of its accession. In a few cases, the year when a PTA enters into force or the year a state joins an existing PTA is not available. In those cases, we rely on the year in which the negotiations leading to the arrangement's formation or expansion were completed. The GATT/WTO only lists PTAs whose members are parties to the GATT and only does so when these agreements are officially notified to it. Thus for some PTAs, the date given by the WTO as to when states enter the preferential arrangement differs from the date furnished by the other sources listed above. In these cases, we use the earliest date. For a further explanation of how we code the formation of PTAs, see Mansfield 1998.

28. See Jaggers and Gurr 1995; and Gurr, Jaggers, and Moore 1989.

29. For example, the measure developed by Przeworski et al. treats regime type as dichotomous. Przeworski et al. 2000.

30. For example, Gastil 1980 and 1990.

31. See, for example, Bollen 1980; Gasiorowski 1996; Gastil 1980 and 1990; and Przeworski et al. 2000 . 
$i$ and which one is $j$ is randomly determined. Recall that our model (Proposition 4) demonstrates that the probability of concluding a trade agreement increases as each participant becomes more democratic. Hence, we expect that both $\beta_{1}$ and $\beta_{2}$ will be positive and that there will be no significant difference between them.

Besides countries' regime types, other factors are likely to influence the formation of PTAs, and we account for their effects as well. As we indicated previously, a number of economic factors may condition a country's decision to join a trade agreement. The size of its domestic market is one such factor. States with larger home markets tend to depend less on trade and may therefore have less reason to conclude agreements that expand their access to foreign markets than economically smaller states. To address this possibility, we include $G D P_{i}$ and $G D P_{j}$ in equation (4). These variables are the gross domestic products (GDPs) of states $i$ and $j$ in year $\tau$. Furthermore, economic conditions may affect the probability that countries sign trade agreements. Some observers, for example, have argued that downturns in the business cycle may stimulate the formation of cooperative agreements. ${ }^{32}$ Therefore, we analyze the effects of $\Delta G D P_{i}$ and $\triangle G D P_{j}$, which are the changes in the GDP of $i$ and $j$ from year $\tau-1$ to $\tau$, and are used here as rough measures of the business cycle in each state. ${ }^{33}$ Controlling for such economic factors is important so that we can establish the independent effects of domestic political institutions.

In addition to political and economic conditions within countries, relations between countries are likely to affect their willingness to form a PTA. ${ }^{34}$ Many observers, for example, argue that the amount of economic exchange between states influences whether they enter a preferential grouping. Rising economic intercourse may increase the prospects of PTA formation by fostering the growth of coalitions with an interest in developing institutional mechanisms to promote greater economic integration and avert the breakdown of economic relations among the group's members. ${ }^{35}$ In the same vein, increasing trade flows can heighten the susceptibility of private traders to opportunistic behavior by foreign governments, prompting firms to press for the establishment of PTAs to reduce the ability of governments to engage in such behavior. ${ }^{36}$ We therefore include $T R A D E_{i j}$, which is the flow of exports from $i$ to $j$ in year $\tau$, in equation (4). ${ }^{37}$

32. Mattli 1999.

33. Data on GDP and the change in GDP are taken from Summers and Heston 1991; and Maddison 1995. Note that while we measure the change in GDP from year $\tau-1$ to year $\tau$, we also estimated equation (4) after measuring both $\triangle G D P_{i}$ and $\triangle G D P_{j}$ from $\tau$ to $\tau+1$. These two sets of results are very similar.

34. Note that using country-pairs-rather than individual countries-as the unit of analysis allows us to control for the effects of both domestic and international influences on PTA formation.

35. Nye 1988, 239

36. Yarbrough and Yarbrough 1992.

37. Data on trade flows are taken from the International Monetary Fund's Direction of Foreign Trade, various years. Note that these data and those on GDP are expressed in U.S. dollars and in real terms: they are deflated using the United States wholesale price index and producer price index. 
The nature of political relations between $i$ and $j$ is also likely to affect their willingness to form a PTA. It is widely recognized, for example, that various countries have established trade agreements with their former colonies, partly to maintain political influence over colonial possessions once they become independent states. ${ }^{38}$ In addition, Cold War dynamics affected international economic relations during the period analyzed here and may have contributed to the establishment of PTAs since World War II. To control for such dynamics - and security relations more generally-we analyze the effects of political-military alliances and military disputes on PTAs.

Countries may be more likely to enter PTAs with their allies than with other states. Trade liberalization yields efficiency gains that enhance the political-military capacity of participants, and alliances help to internalize these security externalities. ${ }^{39}$ Since PTAs liberalize commerce among members, alliance politics may influence the likelihood that states will establish such an agreement. It is also important to take account of military disputes since such events obviously might discourage participants from forming a commercial agreement. We therefore in clude DISPUTE $E_{i j}, C O L_{i j}$, and $A L L Y_{i j}$. The first of these variables equals 1 if $i$ and $j$ are embroiled in a military dispute in $\tau$ and 0 otherwise. The second variable equals 1 if $i$ and $j$ had a colonial relationship (ending after World War II) in $\tau$ and 0 otherwise. The third variable equals 1 if $i$ and $j$ are allies in $\tau$ and 0 otherwise. ${ }^{40}$

The geographical distance between states is another factor that is likely to influence their willingness to enter a PTA. One reason why states form PTAs is to guarantee and expand access to the markets of their key trade partners. ${ }^{4 !}$ Frequently, a country's primary commercial partners are located in relative proximity, since as the distance between states increases, so do transportation costs and various other impediments to commerce. ${ }^{42}$ To account for the effects of geographical proximity on the establishment and expansion of commercial agreements, we include DIS$T A N C E_{i j}$ in equation (4). ${ }^{43}$ We mentioned earlier that many of the PTAs in our sample were formed under the auspices of the GATT. To analyze whether members of this organization have been more likely to establish trading arrangements than other states, we include $G A T T_{i j}$. This variable equals 1 if both $i$ and $j$ are parties to the GATT in $\tau$ and 0 otherwise.

The factors just described pertain to conditions within countries and relations between them, but systemic conditions may affect the formation of PTAs as well. Particularly important in this regard is the influence of hegemony. Since various

38. See Grilli 1993; and Pomfret 1988, 163.

39. See Gowa 1994; and Gowa and Mansfield 1993.

40. Data on military disputes are taken from Jones, Bremer, and Singer 1996. Data on former colonial relations are taken from Kurian 1992. Data on alliances are taken from Small and Singer 1969; and the Correlates of War Project 1993.

41. Whalley 1998.

42. Frankel, Stein, and Wei 1998.

43. Data on distance are taken from Oneal and Russett 1999. 
studies have concluded that waning hegemony tends to stimulate the proliferation of PTAs, we analyze $H E G E M O N Y$, which is the percentage of global trade accounted for by the state that conducts the greatest amount of commerce in a given year. ${ }^{44}$ Finally, $e_{i j}$ is a stochastic error term.

Since comprehensive data on both PTAs and the independent variables described above are only available for the period after World War II, we focus our analysis on this era. More specifically, our sample includes all pairs of countries for which complete data on the variables in equation (4) are available for at least part of the period from 1951 to $1992 .^{45}$ To estimate this model, we pool the available data across time and country-pairs and then conduct a logistic regression. Following Nathaniel Beck, Jonathan N. Katz, and Richard Tucker, we account for any temporal dependence in the data by including a natural spline function (with three knots) of the number of years that have elapsed (as of year $\tau+1$ ) since each pair of states, $i$ and $j$, last formed a PTA. ${ }^{46}$ To conserve space, however, we do not present the estimates of this function. ${ }^{47}$ In addition, the tests of statistical significance we report are based on Huber (robust) standard errors, which account for the grouped nature of the data (in the present case, by country-pairs). Recent research indicates that they are superior to logit standard errors in time-series cross-section models with a binary dependent variable. ${ }^{48}$

\section{The Statistical Results}

The first column of Table 1 contains our initial results. Consistent with the propositions derived from our formal model, the estimated coefficients of $R E G_{i}$ and $R E G_{j}$ are both positive and statistically significant, indicating that the likelihood of establishing a trade agreement rises as each state in a given dyad becomes more democratic. ${ }^{49}$ Moreover, the effects of regime type on commercial cooperation do not vary between states $i$ and $j$. Indeed, there is no statistically significant difference between the estimates of $R E G_{i}$ and $R E G_{j}\left(\chi^{2}=0.26 ; p=.61\right)$.

44. See Bhagwati 1993; Gilpin 1987; Krugman 1993; and Mansfield 1998. This measure of hegemony has been used repeatedly in studies of the international political economy. See, for example, Krasner 1976; Lake 1988; Mansfield 1998; and McKeown 1991. Note that global trade is defined as the sum of total global exports and total global imports and that, for each year analyzed below, the United States is the state having the highest percentage of global trade. Data used to construct this variable are taken from the International Monetary Fund's International Financial Statistics, various years.

45. Only those countries listed by Singer and Small as members of the international system are included in our sample. Singer and Small 1994.

46. See Beck and Katz 1997; and Beck and Tucker 1996.

47. Note that the base of the spline function and each of the three knots are statistically significant in all of the following analyses.

48. See Beck and Katz 1997; and Beck and Tucker 1996.

49. We also sorted these variables by their size, assigning $R E G_{i}$ the larger annual regime score in each pair and $R E G_{j}$ the lower score. This procedure, which accords with much of the literature on the democratic peace, yields estimates that are very similar to those reported below. See, for example, Russett and Oneal 2001; and Russett, Oneal, and Davis 1998. 
TABLE 1. Effects of regime type, GDP, the change in GDP, trade, military disputes, colonial relations, alliances, distance, the GATT, and hegemony on PTA formation, 1951-1992

\begin{tabular}{|c|c|c|c|c|}
\hline Variable & (l) & (2) & (3) & (4) \\
\hline Intercept & $\begin{array}{l}7.315^{* *} \\
(11.85)\end{array}$ & $\begin{array}{l}7.223 * * * \\
(11.64)\end{array}$ & $\begin{array}{l}6.847^{* * *} \\
(11.82)\end{array}$ & $\begin{array}{l}7.212^{* * *} \\
(11.54)\end{array}$ \\
\hline$R E G_{i}$ & $\begin{array}{l}0.038^{* * *} \\
(8.89)\end{array}$ & $\begin{array}{l}0.038^{* * *} \\
(8.80)\end{array}$ & $\begin{array}{l}0.035^{* *} \\
(8.84)\end{array}$ & $\begin{array}{l}0.038^{* *} \\
(8.93)\end{array}$ \\
\hline$R E G_{j}$ & $\begin{array}{l}0.035^{* *} \\
(8.47)\end{array}$ & $\begin{array}{l}0.035^{* *} \\
(8.40)\end{array}$ & $\begin{array}{l}0.032^{* *} \\
(8.15)\end{array}$ & $\begin{array}{l}0.035^{* *} \\
(8.51)\end{array}$ \\
\hline$G D P_{i}$ & $\begin{array}{c}-4.84 \times 10^{-10 * *} \\
(-3.29)\end{array}$ & $\begin{array}{c}-3.29 \times 10^{-10 * *} \\
(-3.47)\end{array}$ & $\begin{array}{c}-7.75 \times 10^{-10_{* *}} \\
(-4.26)\end{array}$ & $\begin{array}{c}-4.89 \times 10^{-10 * *} \\
(-3.34)\end{array}$ \\
\hline$G D P_{j}$ & $\begin{array}{c}-3.84 \times 10^{-10 *} \\
(-2.39)\end{array}$ & $\begin{array}{c}-2.26 \times 10^{-10 *} \\
(-2.16)\end{array}$ & $\begin{array}{c}-6.94 \times 10^{-10 * *} \\
(-4.17)\end{array}$ & $\begin{array}{c}-3.88 \times 10^{-10 *} \\
(-2.43)\end{array}$ \\
\hline$\Delta G D P_{i}$ & $\begin{array}{c}4.72 \times 10^{-9} \\
(1.28)\end{array}$ & & $\begin{array}{c}6.41 \times 10^{-9} \\
(1.55)\end{array}$ & $\begin{array}{c}4.63 \times 10^{-9} \\
(1.26)\end{array}$ \\
\hline$\Delta G D P_{j}$ & $\begin{array}{c}4.85 \times 10^{-9} \\
(1.71)\end{array}$ & & $\begin{array}{c}6.88 \times 10^{-9 *} \\
(2.04)\end{array}$ & $\begin{array}{c}4.77 \times 10^{-9} \\
(1.69)\end{array}$ \\
\hline$T R A D E_{i j}$ & $\begin{array}{c}-1.21 \times 10^{-7} \\
(-1.53)\end{array}$ & $\begin{array}{c}-1.23 \times 10^{-7} \\
(-1.56)\end{array}$ & & $\begin{array}{c}-1.18 \times 10^{-7} \\
(-1.52)\end{array}$ \\
\hline DISPUTE $_{i, j}$ & $\begin{array}{l}-0.740 \\
(-1.91)\end{array}$ & $\begin{array}{l}-0.734 \\
(-1.89)\end{array}$ & $\begin{array}{l}-0.620 \\
(-1.64)\end{array}$ & \\
\hline$C O L_{i j}$ & $\begin{array}{l}1.338^{* *} \\
(8.74)\end{array}$ & $\begin{array}{l}1.327 * * \\
(8.73)\end{array}$ & $\begin{array}{l}1.356^{* *} \\
(8.62)\end{array}$ & $\begin{array}{l}1.324 * * \\
(8.45)\end{array}$ \\
\hline$A L L Y_{i j}$ & $\begin{array}{l}0.665^{* *} \\
(9.70)\end{array}$ & $\begin{array}{l}0.663^{* *} \\
(9.69)\end{array}$ & $\begin{array}{l}0.645^{* *} \\
(9.34)\end{array}$ & $\begin{array}{l}0.673^{* * *} \\
(9.73)\end{array}$ \\
\hline DISTANCE $_{i j}$ & $\begin{array}{l}-0.731 * * \\
(-17.51)\end{array}$ & $\begin{array}{l}-0.730^{* *} \\
(-17.47)\end{array}$ & $\begin{array}{c}-0.681^{* * *} \\
(-20.20)\end{array}$ & $\begin{array}{l}-0.717^{* *} \\
(-16.62)\end{array}$ \\
\hline$G A T T_{i j}$ & $\begin{array}{l}0.391^{* *} \\
(6.05)\end{array}$ & $\begin{array}{l}0.389^{* *} \\
(6.03)\end{array}$ & $\begin{array}{l}0.376 * * \\
(5.79)\end{array}$ & $\begin{array}{l}0.396^{* * *} \\
(6.12)\end{array}$ \\
\hline HEGEMONY & $\begin{array}{l}-53.75^{* *} \\
(-14.92)\end{array}$ & $\begin{array}{l}-53.07 * * \\
(-14.73)\end{array}$ & $\begin{array}{l}-52.29^{* *} \\
(-14.68)\end{array}$ & $\begin{array}{l}-53.84 * * \\
(-14.93)\end{array}$ \\
\hline $\begin{array}{l}\chi^{2} \\
\text { Log likelihood }\end{array}$ & $\begin{array}{l}1915.28 * * \\
-7146.54\end{array}$ & $\begin{array}{l}1906.12^{* * *} \\
-7147.73\end{array}$ & $\begin{array}{l}1866.84^{* * *} \\
-7173.51\end{array}$ & $\begin{aligned} & 1911.48 * * \\
&-7149.97\end{aligned}$ \\
\hline
\end{tabular}

Note: These parameters are estimated using logistic regression, after including a natural spline function with three knots. Figures in parentheses are asymptotic $z$-statistics computed using Huber standard errors. In each model, $N=223,568$.

$*^{*} p \leq .001$. Two-tailed tests are conducted for all estimates.

$*_{p} \leq .05$. Two-tailed tests are conducted for all estimates.

Furthermore, the effects of regime type on PTA formation are quantitatively large. To gauge the magnitude of these effects, we derive the predicted probability of a pair of states establishing a trade agreement if both of them are highly democratic (that is, if $R E G_{i}=R E G_{j}=10$ ), if one is highly democratic and the other is highly autocratic (that is, if $R E G_{i}=10$ and $R E G_{j}=-10$ ), and if both are highly 
TABLE 2. The influence of regime type on the predicted probability of a dyad forming a PTA and the predicted number of dyads forming a PTA

\begin{tabular}{lcc}
\hline \multicolumn{1}{c}{ Regime types of $i$ and $j$} & $\begin{array}{c}\text { Predicted probability of } \\
\text { a dyad forming a PTA }\end{array}$ & $\begin{array}{c}\text { Predicted annual number } \\
\text { of dyads forming a PTA }\end{array}$ \\
\hline Two democracies & .0057 & 30.3 \\
One democracy and one autocracy & .0028 & 14.9 \\
Two autocracies & .0013 & 6.9 \\
\hline
\end{tabular}

"To compute these predicted probabilities, we use the estimates in the first column of Table 1 . We assume that $i$ and $j$ are not involved in a military dispute, that they do not have a prior colonial relationship, and that they are neither allies nor parties to the GATT (that is, DISPUTE $E_{i j}=C_{i j}=$ $A L L Y_{i j}=G A T T_{i j}=0$ ). All remaining variables are evaluated at their means.

${ }^{\mathrm{b}}$ These figures are computed by multiplying the predicted probability of a dyad forming a PTA by the total number of observations in the sample $(223,568)$ and then dividing that product by the number of years in the sample (42).

autocratic (that is, if $\left.R E G_{i}=R E G_{j}=-10\right) .{ }^{50}$ Since the modal pair of states in our sample is not involved in a military dispute, did not have a colonial relationship, and is not made up of either allies or parties to the GATT, we set DISPUTE $i j, C O L_{i j}$, $A L L Y_{i j}$, and $G A T T_{i j}$ equal to zero to compute these probabilities. The remaining variables in equation (4) are evaluated at their means.

As Table 2 shows, on average, the probability of a democracy entering a trade agreement is roughly double the probability of an autocracy doing so. Pairs of democracies are about twice as likely to form a PTA as are pairs composed of a democracy and an autocracy. The latter pairs, in turn, are about twice as likely to engage in commercial cooperation as are autocratic pairs. Expressed in terms of the predicted number of dyads forming a PTA, our results indicate that roughly 30 democratic pairs, 15 mixed pairs, and only 7 autocratic pairs are expected to enter into a trade agreement in an average year.

Turning to the remaining variables, there is evidence that the economic size of countries affects their propensity to enter PTAs. The estimates of $G D P_{i}$ and $G D P_{j}$ are negative and statistically significant, indicating that the likelihood of a country joining a commercial agreement increases as the size of its home market declines. As expected, political relations between states also influence the likelihood that they will join a cooperative agreement. That the estimates of $C O L_{i j}, A L L Y_{i j}$, and $G A T T_{i j}$ are positive and statistically significant indicates that states with a prior colonial

50. In evaluating the probability of a PTA between a democracy and an autocracy, our decision to consider the case where state $i$ is the democracy and state $j$ is the autocracy is entirely arbitrary. The predicted probability under these conditions is virtually identical to the predicted probability when $i$ is the autocracy and $j$ is the democracy. 
relationship, those that are political-military allies, and those that are parties to the GATT are especially likely to enter a PTA. In addition, trade agreements tend to form between states located in proximity to each other and during periods of waning hegemony, since the estimates of DISTANCE $E_{i j}$ and HEGEMONY are negative and significant.

Equally noteworthy is that the business cycle, trade flows, and military disputes have relatively little influence on whether or not states join the same PTA. The positive estimates of $\triangle G D P_{i}$ and $\triangle G D P_{j}$ imply that economic expansion increases the prospects that states will accede to a commercial agreement, whereas the negative estimates of $T R A D E_{i j}$ and $D I S P U T E_{i j}$ suggest that heightened trade flows and military disputes discourage the establishment of PTAs. None of these estimates, however, are statistically significant.

Having estimated the effects of regime type on PTA formation, it is important to assess the robustness of our results. To this end, we begin by dropping $\triangle G D P_{i}$, $\triangle G D P_{j}, T R A D E_{i j}$, and DISPUTE $E_{i j}$ - the variables that are not statistically significant based on our initial findings. As the second, third, and fourth columns of Table 1 show, doing so has little bearing on the remaining estimates.

We also address whether our results depend on the use of Jaggers and Gurr's index of regime type. As noted earlier, there are important reasons to rely on this measure, given our objectives. However, Adam Przeworski, Michael E. Alvarez, José Antonio Cheibub, and Fernando Limongi have developed another measure of regime type that taps the domestic institutions emphasized in our model. ${ }^{51}$ They code states in which "those who govern are selected through contested elections" as democratic and all other states as autocratic. ${ }^{52}$ The data compiled by Przeworski et al. cover fewer countries and years than are included in our initial analyses, and their dichotomous measure is not as well-suited to testing our model as Jaggers and Gurr's index. But the stress they place on whether or not elections are contested in coding a state's regime type is consistent with our model.

To further assess the robustness of our results, we therefore redefine $R E G_{i}$ and $R E G_{j}$ as dummy variables that equal 1 if Przeworski et al. code states $i$ and $j$, respectively, as democratic in year $\tau$ and 0 otherwise. We then estimate the parameters in equation (4) again. As with the findings presented in Table 1, the estimated coefficients of both $R E G_{i}$ and $R E G_{j}$ are positive and statistically significant. ${ }^{53}$ Furthermore, there continues to be no evidence of a significant difference between them. Equally important, the quantitative effects of regime type generated using Przeworski et al.'s data are much the same as those generated using Jaggers and Gurr's data. Based on Przeworski et al.'s measure of regime type, for example, a democracy is roughly three-quarters more likely to enter a PTA than an autocracy,

51. Przeworski et al. 2000 .

52. Ibid., 15

53. More specifically, the estimate of $R E G_{i}$ is .509 , the estimate of $R E G_{j}$ is .580 , and both estimates are statistically significant at the .001 level. 
and democratic pairs are about three times as likely to join a trade agreement as autocratic pairs. Thus our findings are quite robust with respect to the data used to measure regime type.

Next, we include a number of additional factors in equation (4) that might influence the formation of PTAs. First, there is reason to expect that pairs of states belonging to the same PTA will have less incentive to enter (another) one than pairs that are not already party to the same arrangement. We therefore include a variable indicating whether $i$ and $j$ are already members of a common PTA in year $\tau$. Second, it is widely argued that, due to strategic interaction among countries competing in international markets and for other reasons, PTAs tend to form in reaction to one another. ${ }^{54}$ This implies that states are especially likely to establish a commercial agreement soon after the creation of other agreements. As such, we include the number of PTAs formed in year $\tau-1$.

Third, we include a variable indicating whether $i$ and $j$ have command economies in $\tau$. All countries marked by the existence of a command economy are nondemocratic, and such countries rarely have entered preferential groupings. Hence, we need to ensure that the observed relationship between regime type and PTA formation does not stem from the effects of command economies. ${ }^{55}$ Fourth, we include a time trend to account for any secular changes in the global economy that might influence the establishment of PTAs. In addition, we estimate equation (4) using conditional logistic regression-a technique that is equivalent to including pair-specific fixed effects in the model-to account for any heterogeneity in the data. ${ }^{56}$

Regardless of whether we include the variables just described separately or together and regardless of whether equation (4) is estimated using conditional logistic regression, the estimates of $R E G_{i}$ and $R E G_{j}$ remain positive and statistically significant. ${ }^{57}$ Equally, there is virtually no change in these estimates when we redefine the dependent variable in equation (4) as the existence of a PTA between $i$ and $j$ in year $\tau+1$, rather than the formation of a preferential grouping between them. Recall that the observed value of $P T A_{i j}$ is 1 if a PTA forms between $i$ and $j$ in $\tau+1$, and 0 otherwise. When we recode this variable as 1 in all years, $\tau+1$,

54. See de Melo and Panagariya 1993, 5-6; Fernández and Portes 1998; Mansfield 1998; Oye 1992; and Pomfret 1988.

55. Data on command economies are taken from Kornai 1992.

56. Greene 1993, chap. 16.

57. Estimating our model using conditional logistic regression leads to the omission of roughly 85 percent of the observations in our data, since most country-pairs included in the analysis did not form a PTA during the period since World War II. Furthermore, using this estimation procedure to analyze cross-section time-series data with a binary dependent variable has serious drawbacks. See Beck and Katz 2001; and King 2001. Nonetheless, when equation (4) is estimated using this procedure, the estimate of $R E G_{i}$ is .028 , the estimate of $R E G_{j}$ is .023 , and both estimates are statistically significant at the .001 level. Of course, factors that are specific to time might also affect the formation of PTAs. A common way of addressing these factors is to include year-specific fixed effects, but these effects are perfectly correlated with $H E G E M O N Y$, which takes on a different value in each year we examine. 
where $i$ and $j$ belong to the same PTA-regardless of whether the arrangement was formed in $\tau+1$-the results are much the same as those reported in Table 1 . In still another analysis, we eliminated all observations for a given country-pair after that pair formed a PTA. Since the probability of states forming a PTA is likely to be lower if they already belong to one than if they do not, this is another useful check on our earlier results. The results are again quite similar to those in Table 1 (although it is interesting that the size of the estimates of both $R E G_{i}$ and $R E G_{j}$ increase by about one-third). These analyses, then, continue to indicate the robustness of our findings.

Finally, the formation of a PTA is a rare event. Gary King and Langche Zeng have recently argued that using logistic regression to estimate the probability of rare events can yield biased results. ${ }^{58}$ They have developed methods to correct such biases, and we use these methods to generate another set of estimates of the parameters in equation (4). The resulting estimates and standard errors are very similar to those in Table 1, demonstrating that our findings do not suffer from a rare events bias. ${ }^{59}$

In sum, our statistical results strongly support the propositions developed earlierparticularly the proposition that the likelihood of signing a trade agreement rises with the degree of democracy in each country. During the period since World War II, more democratic states have displayed a greater propensity to enter trade agreements than less democratic states, even after controlling for a host of other economic and political factors. Furthermore, the probability of a pair of countries forming a commercial agreement is highest if both countries are democratic and is lowest if both are autocratic.

\section{Conclusion}

We have argued that the regime type of states can strongly affect their propensity to cooperate on economic issues. Leaders in democracies have a greater incentive to pursue international cooperation in trade than do their nondemocratic counterparts. We developed this argument using a formal model of trade policymaking emphasizing the electoral constraints faced by political leaders. Although there are many reasons why countries choose to cooperate, our analysis emphasizes how a country's regime type creates domestic political incentives for leaders that influence this choice.

Our model assumes that both democratic and autocratic leaders would like to maximize the rents stemming from trade barriers, but that both may lose office if their rent seeking becomes excessive. The problem faced by voters and leaders,

58. King and Zeng 2001 .

59. This result is not unexpected, since King and Zeng point out that the influence of their methods will be most pronounced when the number of observations being analyzed is less than a few thousand. King and Zeng 2001. Our sample is obviously much larger than that size. 
however, is that voters have incomplete information about their leaders' behavior: they do not know exactly what trade policy their leaders have chosen at any point in time. And domestic executives cannot credibly commit to accurately divulge this information. Hence, when exogenous shocks adversely influence the economy, an incumbent executive may be voted out of office not because the executive was too extractive, but rather because voters mistakenly assume that the executive was engaged in protectionist predation. The prospect of losing elections due to factors beyond the incumbent executive's control provides a strong incentive to find ways of reassuring voters that the government is not being too extractive. Trade agreements are one such means.

Commercial agreements can mitigate the executive's informational problem. The monitors of these agreements-either countries that are party to them or the international trade institutions themselves - can credibly signal to voters whether their leader is cheating or abiding by the agreement. Accusations of cheating against one's government by foreign countries or an international institution are newsworthy events that can alert (at least some) voters to the government's behavior. Because of this signal, executives can improve their chances of re-election. In democracies, however, voters have a greater impact on the tenure of leaders than in autocracies, since the democratic electorate can more easily turn incumbents out of office. Since autocratic leaders face fewer worries about re-election, they have fewer incentives to relinquish policy autonomy and sign trade agreements, making them less likely than more democratic leaders to seek commercial cooperation. The greater accountability of leaders to voters in democracies makes a difference. Surprisingly, this result is obtained even though democratic executives discount the future more heavily than their autocratic counterparts.

In our model, international agreements serve a domestic purpose. They allow executives to commit themselves credibly to actions that voters would otherwise find incredible. Unilateral trade barrier reductions are less credible to voters and more easily repealed than are mutually agreed-upon international reductions. Others have argued that international institutions promote cooperation by providing information, but they have been less specific about how this mechanism actually induces leaders to choose cooperation. ${ }^{60}$ Here, we identify one mechanism by which cooperative agreements can convey information to voters about the behavior of their leaders, thus allowing voters to better judge their leaders. Other mechanisms might serve this purpose as well, but our claim is that trade agreements do so especially well. The information provided by trade agreements benefits all of the players in our analysis-voters and governments alike. Existing studies rarely acknowledge that international institutions can serve this function. The tendency for such institutions to be created with monitoring and dispute settlement mechanisms suggests their importance in disseminating information domestically as well as internationally. 
International cooperation can thus generate domestic political benefits for leaders, making them more likely to seek cooperative agreements in the first place.

Our empirical findings strongly support the two central hypotheses stemming from the formal model. Since World War II, more democratic countries have displayed a greater likelihood of concluding trade agreement than other countries, even when holding constant various political and economic influences. Equally, pairs of democratic countries are about twice as likely to form a PTA as are pairs composed of a democracy and an autocracy and roughly four times as likely to form such cooperative agreements as are autocratic pairs. In sum, holding constant Cold War influences, economic variables, and various other factors, we find considerable evidence that democracy promotes commercial cooperation. Clearly, democracy is not alone in promoting such agreements, but our findings indicate that it is a potent impetus to cooperation.

Our study also sheds light on other hypotheses about international cooperation. First, whereas functionalist theories argue that high levels of trade between countries should promote cooperation, we find that trade flows do not have much impact on the probability of signing a commercial agreement. Second, as realist theories suggest, alliances and the existence of a stable hegemon foster cooperation in trade. Somewhat surprisingly, however, military disputes have little bearing on trade agreements. Third, we find that GATT members are especially likely to establish preferential agreements, which accords with the view of neoliberal institutionalists that international institutions can improve the ability of states to cooperate. Even when we account for the effects of these and other potential influences on commercial cooperation, however, domestic politics still affects whether states enter into trade agreements.

Scholars of international relations have displayed a longstanding interest in the sources of economic cooperation. Most research on this topic has been cast at the international level. Far less attention has been paid to the domestic influences on economic cooperation. Our results highlight the drawbacks of ignoring these influences. In addition to systemic and economic factors, the regime types of states strongly condition their likelihood of forging a trade agreement. In commercial matters, democracies are more cooperative than are other states because of the domestic political benefits that can be generated by international trade agreements.

\section{Appendix}

In this economy, the export good is the numeraire, and the domestic price of the import good in period $\tau$ is $p_{\tau}=\pi_{\tau}\left(1+t_{\tau}\right)$. Both goods require capital and labor for production, which occurs with constant returns to scale. Let the economy-wide aggregate endowment of capital $(K)$ relative to labor $(L)$ be $k=K / L$. Factors are perfectly mobile domestically.

Each individual, $l$, owns one unit of labor, which is paid a wage $w\left(p_{\tau}\right)$, and each owns $k^{l}$ units of capital, a unit of which is paid $r\left(p_{\tau}\right)$. Individual preferences for the goods are identical and homothetic in the two goods. An individual $l$ 's (one-period) indirect utility can be written as 


$$
U^{\prime}\left(p_{\tau}\right)=V\left(p_{\tau}\right) I^{\prime}\left(p_{\tau}\right)
$$

where the individual's income is

$$
I^{l}\left(p_{\tau}\right)=w\left(p_{\tau}\right)+r\left(p_{\tau}\right) k^{l}+\boldsymbol{\theta}^{l}\left(p_{\tau}-\pi_{\tau}\right) M\left(p_{\tau}\right)
$$

and where $M\left(p_{\tau}\right)$ is the quantity of imports and

$$
\theta^{\prime}=\frac{w+r k^{\prime}}{w L+r K}
$$

as in Mayer. ${ }^{61}$ The last term implies that tariff revenue is distributed back to individuals in proportion to each individual's share of national factor income.

Voters differ along the single dimension $k^{l}$. Assuming no costs to voting, the tariff preferred by the majority of voters is the ideal tariff of the individual with the median capital-labor endowment ratio. This individual, indexed $m$, is endowed with $k^{m}$ units of capital (and a single unit of labor). Since the importable is labor-intensive and the median individual owns more labor relative to capital than does society as a whole, that is, $k^{m}<k$, the median voter prefers a positive level of trade barriers. Given the realization of the world price, $\pi_{\tau}$, any voter, including the median voter, has an ideal tariff. Maximization of one period utility with respect to $t_{\tau}$ shows that the utility-maximizing tariff for the median voter, $m$, is

$$
t_{\tau}^{m}=-\frac{I}{M^{\prime}\left(p_{\tau}\right)} \frac{\partial \theta^{m} / \partial p}{\theta^{m}}
$$

where $I$ is aggregate income. Note first that the quantity of imports decreases with their price, so that $M^{\prime}\left(p_{\tau}\right)<0$. Since the economy exports a capital-intensive good, and $k^{m}<k$, then $\partial \theta^{m} / \partial p>0$, so the median voter prefers a positive level of trade barriers. ${ }^{62}$

Each individual has a vote in an election. Unlike in Mayer, where the vote is over a tariff policy in a direct democracy setting, here the voters use the election to indicate their support for the incumbent. ${ }^{63}$

Following Ferejohn, we are interested in equilibria where voters follow a simple retrospective voting rule, ${ }^{64}$ in which voter $l$ will choose to reappoint the executive in period $\tau$ if their welfare is at least as good as an endogenously determined threshold value, that is, if $\underline{U}^{l}\left(p_{\tau}\right) \geq \underline{U}^{l}$. Banks and Sundaram have studied the repeated election game between the voter and the executive in a more general setting (they permit variations in the types of executives [adverse selection] in addition to the moral hazard we study here), and they show the existence of a sequential equilibrium of this threshold-type equilibrium, conditioned on currently available public information. ${ }^{65}$

61. Mayer 1984.

62. Ibid.

63. Ibid.

64. Ferejohn 1986.

65. Banks and Sundaram 1993. 
As in Persson et al., we look for an equilibrium in which voters condition their voting decision on their utility in the current period and not on any previous period. ${ }^{66} \mathrm{~A}$ historydependent rule would require commitment across periods to be optimal; here voters reoptimize at the beginning of every period. Moreover, the action of the executive is not conditioned on any of its past actions but rather on the current state-whether the executive currently is in office or not. Hence the equilibrium strategies of interest will be Markov and stationary.

Unlike Banks and Sundaram, we consider only one type of incumbent-the preferences of the government are common knowledge. ${ }^{67}$ An executive removed from office is never reappointed, and there is always another candidate (identical in all respects) available to take over the executive. Moreover, the government moves before the uncertainty is resolved each period. Hence there is nothing to be learned by the voters from the actions of the government.

Recall that $\phi\left(t_{\tau}, \underline{U}^{m}\right)=\operatorname{Pr}\left(U^{m}\left(p_{\tau}\right)>\underline{U}^{m}\right)$, and therefore $\phi_{t}<0$ and $\phi_{\underline{U}^{m}}<0$.

Assumption: $\phi(1, U)=0$ for all $U$.

From equation (2) the executive solves:

$$
\frac{\partial \Gamma}{\partial t}=G_{t}+\delta \sigma \phi_{t} \Gamma=0
$$

for the optimal $t$ in any period. From equations (1) and (2) we have, in equilibrium:

$$
\Gamma=\frac{G(t)}{1-\delta\left[\sigma \phi\left(t, \underline{U}^{m}\right)+(1-\sigma)\right]} .
$$

Substituting equation (6) into equation (5), we have that the optimal trade policy $t^{\circ}$ for the executive satisfies:

$$
G,\left\{1-\delta\left[\sigma \phi\left(t, \underline{U}^{m}\right)+(1-\sigma)\right]\right\}+\delta \sigma \phi_{l} G=0 .
$$

\section{LEMMA A.1: $t$ falls with $\underline{U}^{m}$.}

Proof: Totally differentiating equation (5), we have $\Gamma_{t U} d U+\Gamma_{t t} d t=0$, or $d t^{\circ} / d \underline{U}^{m}=$ $-\left(\Gamma_{t \underline{U}^{m}} / \Gamma_{t}\right)$. Now $\Gamma_{t \underline{U}^{m}}=\delta \sigma \phi_{t \underline{U}^{m}} \Gamma<0$ since $\phi_{t \underline{U}^{m}}<0$ by Leibniz's rule (the tariff and the threshold are strategic substitutes). $\Gamma_{\imath t}<0$ so $\bar{d} t^{\circ} / d \underline{U}^{m}<0$.

For the Leviathan strategy, where $t=1$, we assume that the probability that the median voter re-elects the incumbent is zero when incumbent chooses this strategy: $\phi(1, U)=0$ for all $U>0$. Then the gains to the incumbent executive from choosing $t_{\tau}=1$ at the beginning of any period $\tau$ are $\Gamma(1)=G(1)+\delta(1-\sigma) \Gamma$. A lower tariff $t$ is preferred by the incumbent over the Leviathan tariff when: 


$$
G(t)+\delta \rho\left(t, \underline{U}^{m}, \sigma\right) \Gamma(t) \geq G(1)+\delta(1-\sigma) \Gamma(1) .
$$

Define $\underline{t}$ such that equation (8) is satisfied with equality. Then at $t=t\left(U^{m}, \sigma\right)$ the government is exactly indifferent between the lower tariff and the Leviathan strategy.

Lemma A.2: Define $\hat{U}$ such that $t^{\circ}(\hat{U}, \sigma)=\underline{t}(\hat{U}, \sigma)$. Then $d \underline{t} / d \underline{U}^{m}>0$ for $U<\hat{U}$, and $d \underline{t} / d \underline{U}^{m}<0$ for $U>\hat{U}$.

Proof: Implicit differentiation of equation (8) taking the continuation values as given yields $d \underline{t} / d \underline{U}^{m}=-\delta \sigma \Gamma \phi_{\underline{U^{m}}} /\left(G_{t}+\delta \sigma \Gamma \phi_{t}\right)$. Now the numerator is positive, and the denominator is positive for all $t<t^{\circ}$. So for $U<\hat{U}$ we have $t<t^{\circ}$ and hence $d \underline{t} / d \underline{U}^{m}>0$.

LemMA A.3: Let $\tilde{U}$ satisfy $t^{m}=t^{\circ}(\tilde{U}, \sigma)$. Then the following pair of strategies is a Nash Equilibrium: $t^{*}=\left\{\begin{array}{ll}t^{0}\left(\underline{U}^{m}, \sigma\right) & \text { if } \underline{U}^{m}<\hat{U} \\ 1 & \text { otherwise }\end{array}\right.$ and $\underline{U}^{*}=\left\{\begin{array}{ll}\hat{U} & \text { if } t^{m} \leq t(\hat{U}, \sigma), \\ \tilde{U} & \text { otherwise }\end{array}\right.$.

Proof: Equations (7) and (8) establish that the government is playing a best response to any threshold $\underline{U}^{m}$. The median voter wants to get a tariff as close as possible to her (ex ante) ideal, $t^{m}$. If $t^{m}>\underline{t}$, then the voter sets the threshold to $\tilde{U}$, given that the government responds with $t^{\circ}=t^{m}$. On the other hand, when $t^{m}$ crosses $\underline{t}$, then the voter's ideal tariff lies below that which the government can be constrained to provide. Hence the voters restrict the government to the lowest tariff possible by choosing a threshold at $\hat{U}$. Hence the voters control the executive as much as is possible; the median voter is playing a best response.

Notice that the voters' strategy here is to choose a threshold, which is effectively equivalent to deciding whether to recommend re-election or not. At the moment at which the voter chooses a threshold, a threshold chosen higher than the utility observed is a recommendation to evict; a lower one, a recommendation to re-elect.

Notice that perfection-type refinements here (such as subgame perfection) are not applicable in a non-trivial way. Subgame perfection requires that the equilibrium strategies be Nash in any proper subgame. But there are no proper subgames in this game. For instance, at the moment at which the voter must choose a threshold in any period (effectively deciding to recommend re-election or not) the voter does not know either the state of the world $(\pi)$ or the actions of the executive $(t)$ in that period. Hence the decision point is an information set not a single node.

There is a sense, however, that conditional on the publicly available information, the threat to evict (when experienced utility is low) is credible. Consider again the information set where the voter must choose a threshold. Suppose the payoff that period is low-such that the voter is supposed to recommend (in the equilibrium) eviction (by setting high threshold). Suppose they do not. Then in the next period, the government, aware that low payoffs do not imply eviction, will switch from then on to the Leviathan strategy. Such a failure to evict is clearly worse for the voter, and so the voter will continue to evict when called to do so.

\section{Lemma A.4: The sign of $d \underline{t} / d \sigma$ is indeterminate.}

Proof: Implicit differentiation of equation (8) and by the definition of $\underline{t}$, we have $d \underline{t} / d \sigma=$ $-\delta[G(1)(\phi-1)+G(t)] /\left\{G_{t}[1-\delta(1-\sigma)]+\delta G(1) \sigma \phi_{t}\right\}$. Now the first term in the numerator is negative, while the second is positive. In the denominator, the first term is positive, while the second is negative. 
LEMMA A.5: For any international trade agreement $t^{C} \in\left[t^{m}, t\right]$, the following strategies constitute a Nash equilibrium: $t^{*}=\left\{\begin{array}{cc}t^{C} & \text { if } \sigma>\bar{\sigma}(\delta) \\ 1 & \text { otherwise }\end{array}\right.$ and $\underline{U}^{*}=\left\{\begin{array}{cc}0 & \text { if no alarm sent } \\ \infty & \text { otherwise }\end{array}\right.$

Proof: The optimal deviation for the government is the Leviathan action (since any tariff above $t^{C}$ leads to rejection by the voters). Then the equilibrium dominates defection whenever $\Delta\left(t^{C} ; \sigma\right)>0$ which is equivalent to the condition $\sigma>\left[1-G\left(t^{C}\right) / G(1)\right](1 / \delta-$ 1) $\equiv \bar{\sigma}(\delta)$. As for the voters, once the alarm has (or has not) been sent, changing the threshold will have no effect on their payoffs; hence the equilibrium action is weakly preferred.

Along the equilibrium path, the voter knows more about the actions of the executive than in the unilateral case. However, the state of the world is still unknown-hence perfection refinements are not applicable in a non-trivial way. Nevertheless, at any information set, once reached, it remains optimal for the voters to behave according to the equilibrium strategiesthat is, the equilibrium behavior is optimal conditional on the publicly available information.

Proof of Proposition 1: The condition that $\Delta\left(t^{C} ; \sigma\right)>0$ follows directly from Lemma A. $5 ; \partial \Delta\left(t^{C}, \sigma\right) / \partial \sigma=G(1) /[1-\delta(1-\sigma)]^{2} \delta>0$.

Proof of Proposition 2: $\Delta\left(t^{C} ; \sigma\right)=\delta G\left(t^{C}\right) /(1-\delta) \delta\left\{1-\left[\sigma \phi\left(t^{C}, U\right)+(1-\right.\right.$ $\sigma)]\} /\left\{1-\delta\left[\sigma \phi\left(t^{C}, U\right)+(1-\sigma)\right]\right\}>0$ for all $\sigma$ and $d \Delta\left(t^{C} ; \sigma\right) / d \sigma=\delta G\left(t^{C}\right)(\phi-$ 1) $\left(\delta\left\{1-\left[\sigma \phi\left(\mathrm{t}^{\mathrm{C}}, \mathrm{U}\right)+(1-\sigma)\right]\right\}-1\right) /(1-\delta)\left\{1-\delta\left[\sigma \phi\left(\mathrm{t}^{\mathrm{C}}, \mathrm{U}\right)+(1-\sigma)\right]\right\}^{2}>0$ for all $\sigma$.

Proposition 3: $U^{m}\left[\pi\left(1+t^{C}\right)\right] \geq U^{m}\left[\pi\left(1+t^{*}\right)\right]$ for any $t^{C} \in\left[t^{m}, \underline{t}\right]$.

Proof: $G_{t}>0$ for all $t$; by inspection of equation (7), it must be that at $t=t^{*}, \phi_{t}(t)<$ 0 . Now $\phi_{t}(t)=0$ at $t=t^{m}$ since the voter's utility is maximized, and therefore the probability of re-election is maximized. Therefore $t^{*} \geq t^{m}$. After any agreement, $t^{C} \in\left[t^{m}\right.$, $t], \phi\left(t^{C}\right) \geq \phi\left(t^{*}\right)$ since $\phi_{t}(t)<0$ for all $t>t^{m}$ and hence given any realization of $\pi$, $U^{m}\left[\pi\left(1+t^{c}\right)\right] \geq U^{m}\left[\pi\left(1+t^{*}\right)\right]$.

Proposition 4: $d \operatorname{Pr}\left(P T A_{i j}\right) / d \sigma_{i}>0$ and $d \operatorname{Pr}\left(P T A_{i j}\right) / d \sigma_{j}>0$.

Proof: $d \operatorname{Pr}\left(P T A_{i j}\right) / d \sigma_{i}=F F^{\prime} d \Delta / d \sigma_{i}>0$ since $F^{\prime}>0$ by assumption, Propositions 1 and 2 establish the second term, and $F$ lies between 0 and 1 . The proof for the second case is identical.

\section{References}

Anderson, Kym, and Richard Blackhurst. 1993. Introduction and Summary. In Regional Integration and the Global Trading System, edited by Kym Anderson and Richard Blackhurst, 1-15. London: Harvester Wheatsheaf.

Bagwell, Kyle, and Robert Staiger. 1999. An Economic Theory of GATT. American Economic Review 89 (1):215-48.

Banks, Jeffrey S., and Rangarajan K. Sundaram. 1993. Adverse Selection and Moral Hazard in a Repeated Elections Model. In Political Economy: Institutions, Information, Competition, and Representation, edited by William A. Barnett, Melvin J. Hinich, and Norman J. Schofield, 295-312. Cambridge: Cambridge University Press. 
1998. Optimal Retention in Agency Problems. Journal of Economic Theory 82 (2):293-323.

Beck, Nathaniel, and Jonathan Katz. 1997. The Analysis of Binary Time-Series Cross-Section Data and/or the Democratic Peace. Paper presented at the 14th Annual Meeting of the Political Methodology Group, Columbus, Ohio.

2001. Throwing Out the Baby with the Bath Water: A Comment on Green, Kim, and Yoon. International Organization 55 (2):487-95.

Beck, Nathaniel, and Richard Tucker. 1996. Conflict in Space and Time: Time-Series Cross-Section Analysis with a Binary Dependent Variable. Paper Presented at the 92nd Annual Meeting of the American Political Science Association, San Francisco, Calif.

Bhagwati, Jagdish. 1993. Regionalism and Multilateralism: An Overview. In New Dimensions in Regional Integration, edited by Jaime de Melo and Arvind Panagariya, 22-51. New York: Cambridge University Press.

Bollen, Kenneth A. 1980. Issues in the Comparative Measurement of Political Democracy. American Sociological Review 45 (3):370-90.

Bueno de Mesquita, Bruce, and David Lalman. 1992. War and Reason: Domestic and International Imperatives. New Haven, Conn.: Yale University Press.

Bueno de Mesquita, Bruce, James D. Morrow, Randolph M. Siverson, and Alastair Smith. 1999. An Institutional Explanation of the Democratic Peace. American Political Science Review 93 (4):791-808.

Chittick, William, and Keith Billingsley. 1989. The Structure of Elite Foreign Policy Beliefs. Western Political Quarterly 42 (2):201-24.

Correlates of War Project. 1993. Alliances Data. Unpublished data set, University of Michigan.

Coughlin, P. J. 1992. Probabilistic Voting Theory. Cambridge: Cambridge University Press.

Dahl, Robert. 1971. Polyarchy: Participation and Opposition. New Haven, Conn.: Yale University Press.

de Melo, Jaime, and Arvind Panagariya. 1993. Introduction. In New Dimensions in Regional Integration, edited by Jaime de Melo and Arvind Panagariya, 3-21. New York: Cambridge University Press.

Fearon, James. 1994. Domestic Audiences and the Escalation of International Disputes. American Political Science Review 88 (3):577-92.

Ferejohn, John. 1986. Incumbent Performance and Electoral Control. Public Choice 50 (2):5-25.

Fernández, Raquel, and Jonathan Portes. 1998. Returns to Regionalism: An Evaluation of Nontraditional Gains from Regional Trade Agreements. The World Bank Economic Review 12 (2):197-220.

Fiorina, Morris. 1981. Retrospective Voting in American National Elections. New Haven, Conn.: Yale University Press.

Foroutan, Faezeh. 1993. Regional Integration in Sub-Saharan Africa: Past Experience and Future Prospects. In New Dimensions in Regional Integration, edited by Jaime de Melo and Arvind Panagariya, 234-71. New York: Cambridge University Press.

Frankel, Jeffrey A., Ernesto Stein, and Shang-Jin Wei. 1998. Continental Trading Blocs: Are They Natural or Supernatural? In The Regionalization of the World Economy, edited by Jeffrey A. Frankel, 189-219. Chicago: University of Chicago Press.

Gasiorowski, Mark. 1996. An Overview of the Political Regime Change Dataset. Comparative Political Studies 29 (4):469-83.

Gastil, Raymond D. 1980 and 1990. Freedom in the World: Political Rights and Civil Liberties. New York: Freedom House.

Gaubatz, Kurt Taylor. 1996. Democratic States and Commitment in International Relations. International Organization 50 (1): 109-39.

Gilpin, Robert. 1987. The Political Economy of International Relations. Princeton, N.J.: Princeton University Press.

Gowa, Joanne. 1994. Allies, Adversaries, and International Trade. Princeton, N.J.: Princeton University Press.

Gowa, Joanne, and Edward D. Mansfield. 1993. Power Politics and International Trade. American Political Science Review 87 (2):408-20.

Green, William H. 1993. Econometric Analysis, 2d ed. Englewood Cliffs, N.J.: Prentice Hall. 
Grilli, Enzo R. 1993. The European Community and Developing Countries. Cambridge: Cambridge University Press.

Grossman, Gene, and Elhanan Helpman. 1994. Protection for Sale. American Economic Review 84 (4):833-50.

Gurr, Ted Robert, Keith Jaggers, and Will H. Moore. 1989. Polity II: Political Structures and Regime Change, 1800-1986. Study no. 9263. Ann Arbor, Mich.: Inter-University Consortium for Political and Social Research.

Haggard, Stephan, and Robert Kaufman. 1995. The Political Economy of Democratic Transitions. Princeton, N.J.: Princeton University Press.

Hanlon, Joseph. 1986. Beggar Your Neighbor. London: Villiers Publications.

Hartland-Thunberg, Penelope. 1980. Trading Blocs, U.S. Exports, and World Trade. Boulder, Colo.: Westview Press.

Herrmann, Richard K., Philip E. Tetlock, and Matthew N. Diascro. 2001. How Americans Think About Trade: Reconciling Conflicts among Money, Power, and Principles. International Studies Quarterly 45 (2): 191-218.

International Monetary Fund, Various years. Direction of Foreign Trade. Washington, D.C.: IMF.

—. Various years. International Financial Statistics. Washington, D.C.: IMF.

Jaggers, Keith, and Ted Robert Gurr. 1995. Tracking Democracy's Third Wave with the Polity III Data. Journal of Peace Research 32 (4):469-82.

Jones, Daniel M., Stuart A. Bremer, and J. David Singer. 1996. Militarized Interstate Disputes, 1816-1992: Rationale, Coding Rules, and Empirical Patterns. Conflict Management and Peace Science 15 (2): 163-213.

Keohane, Robert O. 1984. After Hegemony: Cooperation and Discord in the World Political Economy. Princeton, N.J.: Princeton University Press.

Kiewiet, Roderick. 1983. Macroeconomics and Micropolitics. Chicago: University of Chicago Press.

King, Gary. 2001. Proper Nouns and Methodological Propriety: Pooling Dyads in International Relations Data. International Organization 55 (2):497-507.

King, Gary, and Langche Zeng. 2001. Explaining Rare Events in International Relations. International Organization 55 (3):693-715.

Kisanga, Eliawony J. 1991. Industrial and Trade Cooperation in Eastern and Southern Africa. Hong Kong: Avebury.

Kornai, Janos. 1992. The Socialist System: The Political Economy of Communism. Princeton, N.J.: Princeton University Press.

Krasner, Stephen D. 1976. State Power and the Structure of Foreign Trade. World Politics 28 (3):317-47.

Krueger, Anne O. 1999. Are Preferential Trading Arrangements Trade-Liberalizing or Protectionist? Journal of Economic Perspectives 13 (4):105-24.

Krugman, Paul. 1993. Regionalism versus Multilateralism: Analytical Notes. In New Dimensions in Regional Integration, edited by Jaime de Melo and Arvind Panagariya, 58-79. New York: Cambridge University Press.

Kurian, George Thomas. 1992. Encyclopedia of the Third World. 4th ed. Vols. 1-3. New York: Facts on File.

Lake, David A. 1988. Power, Protectionism, and Free Trade: International Sources of U.S. Commercial Strategy. Ithaca, N.Y.: Cornell University Press.

Leeds, Brett Ashley. 1999. Domestic Political Institutions, Credible Commitments and International Cooperation. American Journal of Political Science 43 (4):979-1002.

Lewis-Beck, Michael S. 1988. Economics and Elections: The Major Western Democracies. Ann Arbor: University of Michigan Press.

Maddison, Angus. 1995. Monitoring the World Economy, 1820-1992. Paris: Organization for Economic Cooperation and Development.

Mansfield, Edward D. 1998. The Proliferation of Preferential Trading Arrangements. Journal of Conflict Resolution 42 (5):523 - 43 . 
Mansfield, Edward D., Helen V. Milner, and B. Peter Rosendorff. 2000. Free to Trade: Democracies, Autocracies, and International Trade. American Political Science Review 94 (2):305-21.

Mansfield, Edward D., and Jack Snyder. 1995. Democratization and the Danger of War. International Security 20 (1):5-38.

Martin, Lisa L. 2000. Democratic Commitments: Legislatures and International Cooperation. Princeton, N.J.: Princeton University Press.

Mattli, Walter. 1999. The Logic of Regional Integration: Europe and Beyond. New York: Cambridge University Press.

Mayer, Wolfgang. 1984. Endogenous Tariff Formation. American Economic Review 74 (5):970-85.

McGillivray, Fiona, and Alastair Smith. 2000. Trust and Cooperation Through Agent-Specific Punishments. International Organization 54 (4):809-24.

McKeown, Timothy J. 1991. A Liberal Trading Order? The Long-Run Pattern of Imports to the Advanced Capitalist States. International Studies Quarterly 35 (2):151-72.

Milner, Helen V. 1992. International Theories of Cooperation: Strengths and Weaknesses. World Politics $44(3): 466-96$.

1997. Interests, Institutions, and Information: Domestic Politics and International Relations.

Princeton, N.J.: Princeton University Press.

Nye, Joseph S. 1988. Neorealism and Neoliberalism. World Politics 40 (2):235-51.

Oneal, John R., and Bruce Russett. 1999. Assessing the Liberal Peace with Alternative Specifications: Trade Still Reduces Conflict. Journal of Peace Research 36 (4):423-42.

Orimalade, Adeyinka, and R. E. Ubogu, eds. 1984. Trade and Development in Economic Community of West African States. Delhi: Vikas Publishing.

Oye, Kenneth A. 1992. Economic Discrimination and Political Exchange: World Political Economy in the 1930s and 1980s. Princeton, N.J.: Princeton University Press.

Panagariya, Arvind. 2000. Preferential Trade Liberalization: The Traditional Theory and New Developments. Journal of Economic Literature 38 (2):287-331.

Persson, Torsten, Gerard Roland, and Guido Tabellini. 1997. Separation of Powers and Political Accountability. Quarterly Journal of Economics 112 (4):1163-1202.

Pomfret, Richard. 1988. Unequal Trade: The Economics of Discriminatory International Trade Policies. Oxford: Basil Blackwell.

Powell, G. Bingham. 2000. Elections as Instruments of Democracy. New Haven, Conn.: Yale University Press.

Przeworski, Adam, Michael E. Alvarez, José Antonio Cheibub, and Fernando Limongi. 2000. Democracy and Development: Political Institutions and Well-Being in the World, 1950-1990. New York: Cambridge University Press.

Reinhardt, Eric. 1996. Posturing Parliaments: Ratification, Uncertainty, and International Bargaining. Ph.D. diss., Columbia University, New York.

Remmer, Karen. 1998. Does Democracy Promote Interstate Cooperation? International Studies Quarterly 42 (1):25-52.

Russett, Bruce, and John Oneal. 2001. Triangulating Peace: Democracy, Interdependence, and International Organizations. New York: Norton.

Russett, Bruce, John Oneal, and David R. Davis. 1998. The Third Leg of the Kantian Tripod for Peace. International Organization 52 (3):441-68.

Schumpeter, Joseph. [1942] 1976. Capitalism, Socialism, and Democracy. Reprint, New York: Harper Colophon.

Singer, J. David, and Melvin Small. 1994. Correlates of War Project: International and Civil War Data, 1816-1992. Study no. 9905. Ann Arbor, Mich.: Inter-University Consortium for Political and Social Research.

Small, Melvin, and J. David Singer. 1969. Formal Alliances, 1816-1965: An Extension of the Basic Data. Journal of Peace Research 6 (3):257-82. 
Summers, Robert, and Alan Heston. 1991. The Penn World Table (Mark 5): An Expanded Set of International Comparisons. Quarterly Journal of Economics 106 (2):327-68.

Verdier, Daniel. 1998. Democratic Convergence and Free Trade. International Studies Quarterly 42 (1):1-24.

Whalley, John. 1998. Why Do Countries Seek Regional Trade Agreements? In The Regionalization of the World Economy, edited by Jeffrey A. Frankel, 63-83. Chicago: University of Chicago Press.

World Trade Organization. 1995. Regionalism and the World Trading System. Geneva: WTO.

Yarbrough, Beth V., and Robert M. Yarbrough. 1992. Cooperation and Governance in International Trade: The Strategic Organizational Approach. Princeton, N.J.: Princeton University Press. 